
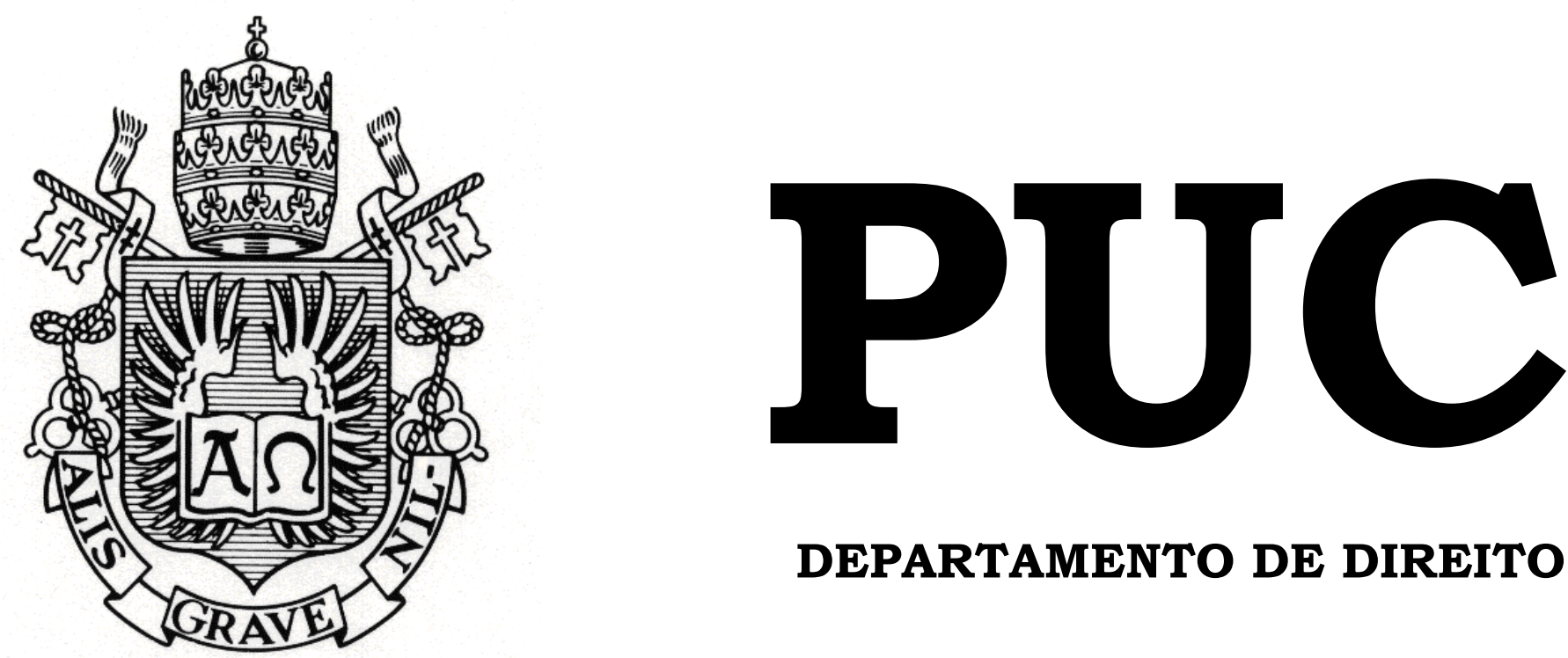

DEPARTAMENTO DE DIREITO

\title{
A PROTEÇÃO DO INDIVÍDUO ATRAVÉS DO JUS COGENS - UMA ANÁLISE DA CORTE INTERAMERICANA DE DIREITOS HUMANOS E DO TRIBUNAL PENAL INTERNACIONAL
}

por

ANA CECÍlIA SABBÁ COLARES

ORIENTADOR(A): Marcia Nina Bernardes

2014.2

PONTIFÍCIA UNIVERSIDADE CATÓLICA DO RIO DE JANEIRO RUA MARQUÊS DE SÃO VICENTE, 225 - CEP 22453-900 


\title{
A PROTEÇÃO DO INDIVÍDUO ATRAVÉS DO JUS COGENS - UMA ANÁLISE DA CORTE INTERAMERICANA DE DIREITOS HUMANOS E DO TRIBUNAL PENAL INTERNACIONAL
}

\author{
por \\ ANA CECÍlIA SABBÁ COLARES
}

Monografia

apresentada

ao

Departamento de Direito da Pontificia Universidade Católica do Rio de Janeiro (PUC-Rio) para a obtenção do Título de Bacharel em Direito.

Orientador(a): Marcia Nina Bernardes 


\section{AGRADECIMENTOS}

A Deus, por ter me permitido chegar até aqui.

A minha família, pelo incondicional apoio financeiro e emocional em todas as etapas da minha graduação.

Ao meu namorado, por toda a paciência e confiança depositada em $\operatorname{mim}$.

As minhas amigas Caroline, Débora, Isadora, Lara, Luísa, Maria Eduarda e Maria Lucia, por terem tornado o caminho mais fácil.

A minha orientadora Marcia, pelo suporte no pouco tempo que lhe coube, pelas suas correções e incentivos.

E a todos que direta ou indiretamente contribuíram para a minha formação, o meu muito obrigada. 


\section{RESUMO}

Esta monografia apresenta um breve estudo sobre a proteção do indivíduo através da aplicação do jus cogens na jurisprudência internacional. Após uma breve análise histórica do significado de se ter no ordenamento internacional uma norma cogente, serão analisadas, especificamente, duas cortes. A nível regional, o Pacto de São José da Costa Rica e a Corte Interamericana de Direitos Humanos, e a nível global, o Estatuto de Roma e o Tribunal Penal Internacional, através de dois casos paradigmáticos de ambos os tribunais. Tudo isso, como uma ilustração das conquistas até então obtidas na proteção e no respeito aos Direitos Humanos no mundo.

Palavras-chave: Jus cogens - Direitos Humanos - Corte Interamericana de Direitos Humanos - Estatuto de Roma do Tribunal Penal Internacional. 


\section{SUMÁRIO}

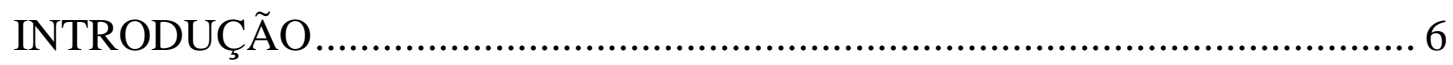

CAPÍTULO 1 - A IMPORTÂNCIA DOS PRINCÍPIOS GERAIS DO DIREITO E A FORMAÇÃO DO JUS COGENS ............................................... 8

CAPÍTULO 2 - A APLICAÇÃO DO CONTEÚDO MATERIAL DE JUS COGENS À LUZ DA JURISPRUDENCIA DA CORTE INTERAMERICANA DE DIREITOS HUMANOS ......................................... 18

2.1. O Pacto de São José da Costa Rica e a Corte Interamericana de Direitos Humanos ................................................................................... 18

2.2. O caso "Almonacid Arellano y otros versus Chile"........................ 22

CAPÍTULO 3 - O JUS COGENS À LUZ DA JURISDIÇÃO UNIVERSAL E DA RESPONSABILIDADE INTERNACIONAL DO INDIVÍDUO............... 37

3.1. O Estatuto de Roma e o Tribunal Penal Internacional ..................... 37

3.2. O caso "The Prosecutor v. Thomas Lubanga Dyilo" ...................... 46

CONSIDERAÇÕES FINAIS …………………………………………… 54

REFERÊNCIAS BIBLIOGRÁFICAS ............................................................ 56 


\section{LISTA DE ABREVIAÇÕES}

ONU - Organização das Nações Unidas

OEA - Organização dos Estados Americanos

SIDH - Sistema Interamericano de Direitos Humanos

CIDH - Comissão Interamericana de Direitos Humanos

TPI - Tribunal Penal Internacional

FPLC - Força Patriótica para Libertação do Congo

UPC - União de Patriotas Congoleses 


\section{INTRODUÇÃO}

O presente estudo tem como objeto de análise as normas cogentes internacionais na seara dos direitos humanos. Tendo o conceito sido formulado pela primeira vez na Convenção de Viena sobre o Direito dos Tratados, em 1969, fora mais um reflexo das amplas conquistas alcançadas em prol dos direitos humanos no pós-Segunda Guerra Mundial e, por isso mesmo, possui intrínseca relação com a proteção desses direitos. Se apresentam como a expressão máxima dos princípios norteadores de um ordenamento internacional protetivo da pessoa humana.

A importância normativa do jus cogens (em posição hierárquica às demais normas internacionais), rende a alguns direitos humanos inclusive a capacidade de colocar em xeque a posição dos Estados como sujeitos absolutos do Direito Internacional, haja vista que nem mesmo tratados multilaterais expressão máxima da soberania do Estado - poderiam derroga-los. Dada a sua diferente posição hierárquica e, consequentemente, a sua relevante importância, é que estas normas precisam tanto ser estudadas: precisam estar bem definidas no contexto o qual se inserem. Por este motivo, o foco deste trabalho é também contribuir para a construção de uma ideia mais clara a respeito de quais seriam efetivamente as chamadas normas imperativas.

Para isso, analisar-se-á o trabalho de duas cortes internacionais. A Corte Interamericana de Direitos Humanos será examinada através do Pacto de São José da Costa Rica e do caso "Almonacid Arellano y otros vs. Chile", "leading-case" no qual a Corte discutiu abertamente a impossibilidade de se anistiar crimes de lesa humanidade por se tratarem de proibições de jus cogens. Por sua vez, o Tribunal Penal Internacional, será analisado através de seu Estatuto, o qual surgira com o propósito de consignar os crimes que a humanidade considera ultrajar a sua consciência - e que por isso mesmo não cometê-los também seriam normas imperativas -, bem como do caso “The 
Prosecutor vs. Thomas Lubanga Dyilo”, o primeiro caso de violação de direitos humanos julgado pelo Tribunal.

Parte-se então, de uma breve análise histórica da criação da ideia e do termo "norma cogente", indissociavelmente atrelada a própria formação histórica dos direitos humanos, para, a partir daí, analisar-se o que vem sendo considerado como jus cogens pela jurisprudência internacional, e qual o tratamento dispensado a estas normas pela mesma. Através de uma análise jurisprudencial das duas cortes, será feito um estudo comparativo de como o indivíduo vem tendo seus direitos protegidos em âmbito regional e global. E como o conceito de jus cogens, quando utilizado, pode ser um mecanismo forte na proteção de determinados direitos. Principalmente, quando tratado de direitos humanos nenhum legisla sobre o tema, como no caso julgado pela Corte Interamericana, o qual ocorrera anteriormente à ratificação do Pacto de São José da Costa Rica pelo Estado do Chile.

Por fim, tendo presente que no decurso dos últimos séculos, milhões de crianças, homens e mulheres foram vítimas de atrocidades inimagináveis que chocam profundamente a consciência da humanidade, as proibições de jus cogens vêm com o propósito de serem fortes bloqueios à reincidência destas barbaridades. Não se subjugam a tratados multilaterais e menos ainda a acordos bilaterais; não podem ser preteridas sob argumentos de prescrição, irretroatividade da lei penal ou até mesmo soberania do Estado, haja vista a criação de todo um arcabouço jurídico pautado na ideia da jurisdição universal, consubstanciado no Tribunal Penal Internacional, para cuidar destas proibições. Contudo, por se tratar de um conceito vago e amplamente controverso, traçar contornos mais bem definidos a estas proibições é uma forma de solidificar tal bloqueio, além de possibilitar que as escusas supramencionadas não sejam aplicadas, em vistas de uma proteção internacional do indivíduo cada vez maior. É este o propósito do trabalho aqui apresentado. 


\section{CAPÍTULO 1 - A IMPORTÂNCIA DOS PRINCÍPIOS GERAIS DO DIREITO E A FORMAÇÃO DO JUS COGENS}

Todo sistema jurídico tem princípios fundamentais, que inspiram, informam e fundamentam suas normas. São os princípios que, evocando as causas primeiras, fontes ou origens das normas e regras conferem coesão, coerência e legitimidade as normas jurídicas e a um sistema jurídico como um todo. São os princípios gerais do direito que conferem ao ordenamento jurídico sua indissociável dimensão axiológica, pois, são eles que nos revelam os valores que inspiram todo o ordenamento e que, em última instância, provem seus próprios fundamentos. ${ }^{1}$ Com o Direito Internacional dos Direitos Humanos não poderia, pois, ser diferente.

Os referidos princípios gerais do direito têm sido reiteradamente reafirmados, ao longo do tempo, e retêm plena validade em nossos dias. Sem eles, não há sistema jurídico algum, seja nacional, seja internacional. Nas palavras de Antônio Augusto Cançado Trindade:

Com efeito, há princípios gerais do direito comuns a todos os sistemas jurídicos nacionais, que se encontram inelutavelmente ligados aos próprios fundamentos do Direito; o direito internacional não faz exceção a isto. Os princípios gerais do direito abarcam igualmente os princípios do próprio direito internacional. Em meu entender, tais princípios informam e conformam as normas e regras do direito internacional, e são uma manifestação da consciência jurídica universal; no ius gentium da evolução, considerações básicas de humanidade exercem um papel de maior importância. ${ }^{2}$

Atrelando-se ao campo de estudo do Direito Internacional dos Direitos Humanos, as causas primeiras ou os princípios que justificam, fundamentam e consolidam o ordenamento jurídico protetivo da pessoa humana remetem a

\footnotetext{
${ }^{1}$ TRINDADE, Antonio Augusto Cançado. Derecho Internacional de los Derechos Humanos Essencia y Trascendencia (Votos em la Corte Interamericana de Derechos Humanos, 1991-2006). México: Edit. Porrúa/Universidad Iberoamericana, 2007. pp. 68-69, pars. 44 e 46.

${ }^{2}$ TRINDADE, Antonio Augusto Cançado. Os Tribunais Internacionais Contemporâneos. Brasília: FUNAG, 2013. p. 72.
} 
fontes jusnaturalistas, que vêm no outro um ser merecedor de igual consideração e profundo respeito desde o seu nascimento. Contudo, por não ser objeto de estudo deste trabalho todo o panorama histórico e filosófico que resultou na Declaração Universal dos Direitos Humanos de 1948, parte-se do ponto em que houve a verdadeira consolidação do Direito Internacional dos Direitos Humanos: meados do século XX, em decorrência da Segunda Guerra Mundial, para tentar ilustrar porque os princípios estão não só nas causas primeiras, na razão de construção de um novo direito, como também na sua consolidação e aplicação qualquer que seja o tempo.

O Direito Internacional dos Direitos Humanos é, pois, um fenômeno do pós-guerra. Seu desenvolvimento pode ser atribuído às monstruosas atrocidades do regime nazista e à crença de que parte destas atrocidades poderiam ser prevenidas se um efetivo sistema de proteção internacional de direitos humanos existisse. É por isso que por mais de meio século, o sistema internacional tem demonstrado comprometimento com valores que transcendem aqueles puramente estatais, e tem desenvolvido um impressionante sistema normativo de proteção dos direitos da pessoa humana, norteados sempre pelo princípio máximo da dignidade inerente ao ser humano - entrave de extermínios como os da primeira metade do século XX.

A internacionalização dos direitos humanos constitui, assim, um movimento extremamente novo na história, que surgiu como resposta às violações e aos horrores cometidos durante os regimes totalitários na Europa, em especial, a Era Hitler. Apresentando o Estado como o grande violador dos direitos do homem e da mulher, essa Era foi marcada pela lógica da destruição e da descartabilidade, que resultou no extermínio de onze milhões de pessoas. ${ }^{3}$

No momento em que os seres humanos se tornam supérfluos e descartáveis, no momento em que vige a lógica da destruição, em que

\footnotetext{
${ }^{3}$ PIOVESAN, Flávia. Direitos Humanos e o Direito Constitucional Internacional. 13 ed., rev. e atual. São Paulo: Ed. Saraiva, 2012. p. 184.
} 
cruelmente se abole o valor da pessoa humana, torna-se necessária a reconstrução desses valores e dos próprios direitos humanos, que se já existiam àquela época, não estavam cumprindo com o seu papel. ${ }^{4}$

A barbárie do totalitarismo na Europa do início do século XX significou a ruptura de tudo que já havia se conquistado até então, por meio da negação do valor do ser humano como um fim em si mesmo. Diante dessa ruptura, emerge a necessidade de (re)construir esses direitos, como referencial e paradigma ético que os reaproxime de alguma moral. Se a Segunda Guerra significou a ruptura com tudo que se havia conquistado em prol da dignidade humana desde os tempos da Revolução Francesa, o pós-guerra deveria significar, portanto, sua reconstrução.

Nasce ainda a certeza de que a proteção de determinados direitos não pode se reduzir ao âmbito reservado de um Estado (muitas vezes o principal perpetrador das violações), porque revela tema de legítimo interesse internacional. É, pois, o fim do paradigma vestfaliano, segundo o qual os Estados soberanos coordenam suas ações sem admitir que nenhuma autoridade exerça qualquer tipo de coerção vertical. ${ }^{5}$ Sob este prisma, a violação dos direitos humanos não pode ser concebida como questão doméstica, e sim como problema de relevância internacional, como legítima preocupação da comunidade dos Estados.

É sob a ótica de tal necessidade que houve o processo de internacionalização desses direitos, culminando na criação de uma sistemática capaz de responsabilizar o Estado no domínio internacional quando as instituições nacionais se mostrassem falhas ou omissas.

Neste contexto, o Tribunal de Nuremberg, em 1945-1946, foi o grande marco deste movimento. Ao final da Segunda Guerra e após calorosos debates sobre como os alemães poderiam ser responsabilizados pela guerra e pelos

\footnotetext{
${ }^{4}$ Ibid. p. 185.

${ }^{5}$ ALMEIDA, João Marques de. A Paz de Westfália - A História do Sistema de Estados Modernos e a Teoria das Relações Internacionais. In: Política Internacional. V. 2. No 18. Lisboa, 1998. p. 45.
} 
bárbaros excessos cometidos, os Aliados chegaram a um consenso, com o Acordo de Londres de 1945, pelo qual ficava convocado um Tribunal Militar Internacional para julgar os criminosos de guerra. ${ }^{6}$

O Tribunal de Nuremberg aplicou fundamentalmente o costume internacional para a condenação criminal de indivíduos envolvidos na prática de crimes contra a paz, crimes de guerra e crimes contra a humanidade, previstos pelo Acordo de Londres. ${ }^{7}$ Tal costume, então considerado, dependia da concordância de um número significativo de Estados em relação a determinada prática; da continuidade desta por considerável período de tempo e da concepção de ser requerida pela ordem internacional e aceita como lei, ou seja, de que havia o senso de obrigação legal. ${ }^{8}$ Desta forma, o senso de obrigação legal foi o elo capaz de reduzir as críticas sob o argumento de que o Tribunal seria uma afronta ao princípio da legalidade.

No entanto, a mais importante contribuição do Tribunal de Nuremberg não foram as 12 condenações à morte, as 3 prisões perpétuas, as 2 condenações a 20 anos de prisão, a condenação a 15 anos, a de 10, ou as três absolvições. ${ }^{9} \mathrm{O}$ significado mais relevante que o Tribunal deixara como legado para a humanidade foi ter consolidado a ideia da necessária limitação da soberania nacional, bem como ter reconhecido que os indivíduos têm direitos protegidos pelo Direito Internacional. Foi a primeira vez que um tribunal julgou um Estado responsável no âmbito internacional, legalmente e politicamente, pelo

\footnotetext{
${ }^{6}$ PIOVESAN, Flávia. Op. cit., p. 187.

${ }^{7}$ Os crimes contra a paz seriam: planejar, preparar, incitar ou contribuir para a guerra, ou participar de um plano comum ou conspiração para a guerra. Os crimes de guerra, consistiriam em violação ao direito costumeiro de guerra, tais como, assassinato, tratamento cruel, deportação de populações civis que estejam ou não em territórios ocupados, para trabalho escravo ou para qualquer outro propósito, assassinato cruel de prisioneiro de guerra ou de pessoas em alto-mar, assassinato de reféns, saques a propriedades públicas ou privadas, destruição de cidades ou vilas, ou devastação injustificada por ordem militar. E, por fim, os crimes contra a humanidade seriam assassinato, extermínio, escravidão, deportação ou outro ato desumano contra a população civil antes ou durante a guerra, ou perseguições baseadas em critérios raciais, políticos e religiosos, independentemente se, em violação ou não, do direito doméstico do país no qual fora perpetrado. (MAZZUOLI, Valerio de Oliveira. Curso de Direito Internacional Público. 5 ed. São Paulo: Editora Revista dos Tribunais, 2011. p. 942-943)

${ }^{8}$ PIOVESAN, Flávia. Op. cit., p. 189

9 Julgamentos de Nuremberg. In: Wikipédia: a enciclopédia livre. Disponível em: http://pt.wikipedia.org/wiki/Julgamentos_de_Nuremberg. Acesso em: 19 jul. 2014.
} 
que ocorreu dentro de seu território, com seus próprios nacionais. Apreende-se, de tal modo, uma mudança drástica nas relações entre os Estados, que vem sinalizar as transformações na compreensão dos direitos humanos, que, a partir de então, não poderiam mais ficar subjugados pela soberania estatal.

Um outro avanço no sentido de resposta às atrocidades cometidas durante a guerra, foi a criação das Nações Unidas de 1945 e a Declaração Universal dos Direitos Humanos de 1948. Esta primeira, instalou um sistema em que as preocupações com a manutenção da paz e da segurança internacional tomaram o topo da pirâmide das prioridades internacionais, notoriamente verificadas com a adoção da cooperação internacional no plano econômico, social e cultural, a proteção ao meio ambiente mas, principalmente, a proteção dos direitos humanos.

Fora através da maciça expansão das organizações internacionais que se pôde verificar uma ruptura entre o antigo direito internacional, que via a sua atuação pautada sempre de acordo com o voluntarismo estatal, para o direito internacional do pós-guerra, que passara a ver na proteção da dignidade humana e na manutenção da paz sua máxima razão de existir. Na análise do Secretário Geral da ONU: “não há desenvolvimento sem segurança; segurança sem desenvolvimento e nem tampouco segurança ou desenvolvimento sem o respeito pelos direitos humanos."

No que diz respeito à Declaração Universal dos Direitos Humanos de 1948, foi o primeiro documento (aprovado por unanimidade) ${ }^{11}$ que buscou firmar um compromisso de ordem pública mundial fundada no respeito supremo à dignidade humana - como forma de reparação e prevenção ao que acontecera no passado. Impedir a descartabilidade. Desde o preâmbulo, é afirmada a dignidade inerente a qualquer pessoa, igualmente titular de

\footnotetext{
${ }^{10}$ In larger freedom: towards development, security and human rights for all. Report of the SecretaryGeneral. In: United Nations, 21 de março de 2005, p. 41-42. Disponível em http://www.un.org/largerfreedon/contents.htm. Acesso em: 27 jun. 2014.

${ }^{11}$ TRINDADE, Antônio Augusto Cançado. Tratado Internacional dos Direitos Humanos. Vol. I. $2^{\text {a }}$ edição. Porto Alegre: Sergio Antonio Fabris Editor, 2003. p. 58.
} 
inalienáveis direitos. Vale dizer, o único requisito para a titularidade de direitos é a condição "pessoa" - seja ela proveniente da onde for, do gênero que possuir, ou da opinião que apresentar. A universalidade dos direitos humanos traduz a absoluta ruptura com o legado nazista, que condicionava a titularidade de direitos à pertinência a determinada raça ariana. ${ }^{12}$

A dignidade humana como fundamento dos direitos humanos e valor intrínseco à condição humana é concepção que, posteriormente, viria a ser incorporada por todos os tratados de direitos humanos, que vieram a formar o próprio Direito Internacional dos Direitos Humanos. Nas palavras de Habermas:

A dignidade humana forma o "portal” através do qual a substancia igualitária e universalista da moralidade é importada para o direito. A ideia de dignidade humana é o eixo conceitual que conecta a moral do igual respeito por cada um ao direito positivo e ao processo legislativo democrático, de tal modo que dessa interação, sob circunstancias históricas favoráveis, pôde se originar uma ordem política fundada nos direitos humanos. ${ }^{13}$

A Declaração surge com uma proposta de plataforma comum de ação, além de consolidar a afirmação de uma ética universal ao consagrar um consenso sobre valores que devem ser seguidos por todos os Estados. O respeito a esses valores, é a premissa básica para o ser humano poder exercer todas as suas potencialidades.

Além de determinados direitos inalienáveis que todo ser humano possui, estes também seriam - segundo a Declaração - indivisíveis e interdependentes, atrelando, pela primeira vez na história, direitos civis, políticos, sociais, econômicos e culturais. Os direitos passam a ser concebidos como uma unidade interdependente e indivisível, fundamentada por determinados princípios - como o da dignidade da pessoa humana -, para que violações como as do inicio do século XX fossem impedidas de ocorrer novamente.

\footnotetext{
${ }^{12}$ PIOVESAN, Flávia. Op. cit., p. 184.

${ }^{13}$ HABERMAS, Jurgen. El concepto de dignidad humana y la utopia realista de los derechos humanos. Trad. Javier Aguirre Román. Rev. Eduardo Mendieta y María Herrera. Dianóia, vol. LV, n ${ }^{\circ}$ 64, mayo, 2010.
} 
São esses mesmos princípios que formaram o que chamar-se-ia hoje de norma cogente internacional. Aquelas normas que nenhum tratado ou acordo pode ir de encontro, por representar a verdadeira razão de existir do Direito Internacional dos Direitos Humanos. Ao se negar uma destas normas, estar-seia negando toda a lógica protetiva da dignidade da pessoa humana e até mesmo, tal dignidade.

Todavia, a expressão jus cogens ou norma cogente internacional, como expressão dos princípios e direitos máximos, indisponíveis e inalienáveis, só viria a aparecer pela primeira vez na legislação internacional na Convenção de Viena sobre o Direito dos Tratados de 1969, mais de 20 anos após a promulgação da Declaração Universal.

Fora Jesus Maria Yepes, na Comissão de Direito Internacional das Nações Unidas, nos debates para a aprovação de uma convenção sobre tratados, que falara em norma imperativa internacional pela primeira vez. Ainda que não tenha utilizado o termo, o colombiano afirmara categoricamente que para sua validez, um tratado não pode ter um objeto ilícito de acordo com o Direito Internacional. E jus cogens são precisamente aquelas normas que a comunidade internacional em seu conjunto considera que não pode haver pacto em contrário. ${ }^{14}$

Neste sentido, a redação do que naquele momento fora o art. 15 da Convenção de Viena era a seguinte:

Um tratado, ou qualquer de suas disposições, é nulo se para seu cumprimento há um ato ilícito de acordo com o Direito Internacional, e se assim o declarar a Corte Internacional de Justiça. ${ }^{15}$

\footnotetext{
${ }^{14}$ ABELLO-GALVIS, Ricardo. Introducción al estúdio de las normas de ius cogens en el seno de la Comisión de Derecho Internacional, CDI. Colombia. Ed: Facultad de Jurisprudencia de La Universidad Del Rosario Centro Editorial Rosarista, 2003. V.5, fasc.1 p. 35 - 76.

15 "A treaty, or any of its provisions, is void if its performance involves an act which is illegal under international law and if it is declared so to be by the International Court of Justice" (TLA). Comissão de Direito Internacional, A/CN, 24 de março de 1953.
} 
Trata-se assim, de um ato ilícito quando se afetam direitos de terceiros Estados, bem como quando viola os princípios basilares do Direito Internacional, causas e fundamentos do mesmo.

O relator da Comissão de Direito Internacional das Nações Unidas (CDI) de 1953 apresentou, então, uma ideia mais clara de jus cogens na medida em que falou se tratar de normas imperativas que freiam e condicionam a liberdade contratual e que se há designado como "princípios superiores de direito internacional.” ${ }^{16} \mathrm{E}$ foi assim que se incorporou positivamente a ideia de jus cogens pela primeira vez no Direito Internacional, no artigo 53 da Convenção de Viena sobre o Direito dos Tratados:

É nulo um tratado que, no momento de sua conclusão, conflite com uma norma imperativa de Direito Internacional geral. Para os fins da presente Convenção, uma norma imperativa de Direito Internacional geral é uma norma aceita e reconhecida pela comunidade internacional dos Estados como um todo, como norma da qual nenhuma derrogação é permitida e que só pode ser modificada por norma ulterior de Direito Internacional geral da mesma natureza. ${ }^{17}$

Embora para alguns autores as características substanciais dessas normas já estivessem presentes no Direito Internacional muito antes da Convenção, ${ }^{18}$ o artigo 64 também previu que se sobrevier uma nova norma imperativa de Direito Internacional geral, qualquer tratado existente que estiver em conflito com essa norma torna-se nulo e extingue-se. ${ }^{19}$

Parte da doutrina vai então no sentido de que o jus cogens seria o mais forte dos mecanismos de limitação da soberania dos Estados, pois, haja vista

\footnotetext{
${ }^{16}$ ABELLO-GALVIS, Ricardo. Introducción al estúdio de las normas de ius cogens en el seno de la Comisión de Derecho Internacional, CDI. Colombia. Ed: Facultad de Jurisprudencia de La Universidad Del Rosario Centro Editorial Rosarista, 2003. V.5, fasc.1 p. 35 - 76.

${ }^{17}$ Convenção de Viena sobre o Direito dos Tratados, artigo 53. U.N. Doc A/CONF.39/27 (1969). Disponível http://treaties.un.org/Pages/ViewDetails.aspx?src=UNTSONLINE\&tabid=2\&id=469\&chapter=23\&lan $\mathrm{g}=\mathrm{fr} \# 1$. Acesso em: 30 jun. 2014.

${ }^{18}$ ZENOVIC, Predrag. Human rights enforcement via peremptory norms - a challenge to state sovereignt. RGSL Research Papers n. 6. Riga, 2012. p. 16.

19 Convenção de Viena sobre o Direito dos Tratados, artigo 64. Disponível em: http://www.planalto.gov.br/ccivil_03/_Ato2007-2010/2009/Decreto/D7030.htm. Acesso em: 31 ago. 2014.
} 
que nenhum tratado é hábil a afastá-lo, os Estados estariam submetidos a estas normas independentemente de acordos ou tratados, que são naturalmente, atos de soberania. Para Predrag Zenovic:

Peremptory human rights norms, as projections of individual and colletive ethics, being the fundamental principles of the international community, materialize as powerful collective values. (...) If certain human rights can be considered jus cogens it subsequently brings superior procedural effects to their implementation in relation to the principles associated with state sovereingty. (...) The principle of sovereign immunity, although it remains an inviolable tenet of international law subject to no exceptions for grave international crimes in national case law, has no legal ground to supervene jus cogens. The argumentation clearly stems from the normative hierarchy advocated in international case law and doctrine. ${ }^{20}$

E o autor ainda complementa que "the normative significance of jus cogens renders human rights capable of changing the state-centric nature of international law, a process entrenched in human rights universalization.”21

Ademais, para alguns autores, o jus cogens também iria além do direito dos tratados, se estenderia ao direito da responsabilidade internacional do Estado e a todo corpus juris do Direito Internacional contemporâneo, abarcando em última instancia a todo ato jurídico. Ao abarcar todo o Direito Internacional, se projetaria também sobre o direito interno dos Estados, invalidando qualquer medida ou ato incompatível com ele. ${ }^{22}$

Contudo, a Convenção de Viena sobre o Direito dos Tratados é ainda hoje o único tratado (em sentido lato) que positivou e conceituou as normas imperativas internacionais, motivo pelo qual o debate é tão intenso. Para o objeto de estudo em análise não ficar então comprometido, o presente trabalho ater-se-á apenas às normas cogentes de direitos humanos, o que implica dizer que maiores considerações sobre igualdade e soberania dos Estados, o

\footnotetext{
${ }^{20}$ ZENOVIC, Predrag. Human rights enforcement via peremptory norms - a challenge to state sovereignt. RGSL Research Papers n. 6. Riga, 2012. p. 4.

${ }^{21}$ Ibid. p. 8.

${ }^{22}$ TRINDADE, Antonio A. Cançado. La ampliación del contenido material del ius cogens. XXXV Curso de Derecho Internacional Organizado por el Comité Jurídico Interamericano - 2008, Washington D.C.: Secretaría General de la OEA, 2009. p. 1.
} 
princípio "pacta sunt servanda" e autodeterminação dos povos só serão realizadas no que pertinente ao foco do estudo.

Assim sendo, na falta de tratados, entender como a jurisprudência e a doutrina vêm reconhecendo o que seria uma norma aceita e reconhecida pela comunidade internacional como um todo, é fundamental para compreender o atual quadro de proteção dos direitos humanos. É disso, pois, que os próximos capítulos irão tratar. 


\section{CAPÍTULO 2 - A APLICAÇÃO DO CONTEÚDO MATERIAL DE JUS COGENS À LUZ DA JURISPRUDENCIA DA CORTE INTERAMERICANA DE DIREITOS HUMANOS}

\subsection{O Pacto de São José da Costa Rica e a Corte Interamericana de Direitos Humanos}

A Corte Interamericana de Direitos Humanos, sediada em São José da Costa Rica, tem como função decidir a respeito das matérias que tangem à Convenção Americana de Direitos Humanos, ou o Pacto de São José da Costa Rica, subscrito em 22 de novembro de 1969 e que entrou em vigor em 18 de julho de $1978 .{ }^{23}$ É hoje, a corte internacional que mais discute e amplia o conteúdo material de jus cogens, utilizando tal conceito como fundamento de inúmeros casos. ${ }^{24}$

O Sistema Interamericano de Direitos Humanos (SIDH) iniciou-se formalmente com a aprovação da "Declaração Americana de Direitos e Deveres do Homem” na $9^{\text {a }}$ Conferencia Internacional Americana realizada em Bogotá em 1948, onde também foi adotada a própria Carta da Organização dos Estados Americanos (OEA), que afirmou os "direitos fundamentais da pessoa humana” como um dos princípios fundadores da Organização, ${ }^{25}$ organismo regional das Nações Unidas, que tivera seu estatuto institucional por meio da Carta. $^{26}$

\footnotetext{
${ }^{23}$ Convenção Americana de Direitos Humanos. In: Wikipédia: a enciclopédia livre. Disponível em: http://pt.wikipedia.org/w/index.php?title=Conteúdo_aberto\&oldid=15696001. Acesso em: 6 jul. 2014.

24 A título ilustrativo, pode-se citar os casos: "Blake vs. Guatemala", "Barrios Altos vs. Peru", "Yatama vs. Nicarágua”, "Servellón Garcia y otros vs. Honduras", "Ximenes Lopez vs. Brasil”, “Goiburú y otros vs. Paraguay”, dentre outros.

${ }^{25} \mathrm{O}$ que é a CIDH. In: Organização dos Estados Americanos - democracia para a paz, segurança e desenvolvimento. Disponível em: http://www.oas.org/pt/cidh/mandato/que.asp. Acesso em: 6 jul. 2014.

${ }^{26}$ HILDEBRANDO, Accioly; G.E. do Nascimento e Silva; CASELLA, Paulo Borba. Manual de Direito Internacional Público. 17 ed. São Paulo: Ed. Saraiva, 2009. p. 438.
} 
Por sua vez, a Corte Interamericana, órgão autônomo da OEA, instalada em 1979, nasceu com o propósito de decidir contenciosos e emitir pareceres jurídicos no que tange às possíveis violações de direitos humanos no continente americano sob a égide da Convenção, ou o Pacto de São José.

A Corte é composta por sete juízes, eleitos pela Assembleia Geral da OEA, com mandato de seis anos cada, que podem ser reconduzidos por uma única vez. A Corte Interamericana admite ainda a participação de juízes ad hoc, quando um dos juízes titulares é nacional de um dos Estados-parte de um processo. $^{27}$

No que diz respeito à competência, a Corte é competente para julgar acontecimentos que se deram apenas nos Estados que ratificaram a Convenção Americana e que reconheceram sua competência, ${ }^{28}$ o que implica dizer que não exerce jurisdição sobre todos os Estados da OEA, a exemplo dos Estados Unidos, que nunca ratificou o tratado.

Além disso, a Corte tem competência material para julgar qualquer violação aos direitos arrolados no Pacto de São José. E vem julgando também, como veremos a seguir, aquelas matérias que considera ser domínio de jus cogens, as quais geram a obrigação erga omnes de não serem violadas independentemente de tratados.

A Corte, contudo, não atua sozinha. Outro órgão autônomo da Organização e que é também encarregado da proteção dos direitos humanos no continente é a Comissão Interamericana de Direitos Humanos (CIDH), criada por resolução da Quinta Reunião de Consulta dos Ministros das Relações Exteriores em Santiago do Chile, em 1959, e formalmente instalada em 1960,

\footnotetext{
${ }^{27}$ VARELLA, Marcelo Dias. Direito Internacional Público. 2 ed. São Paulo: Saraiva, 2010. p. 446.

28 Convenção Interamericana de Direitos Humanos, artigo 62. Disponível em: http://www.pge.sp.gov.br/centrodeestudos/bibliotecavirtual/instrumentos/sanjose.htm. Acesso em 31 ago. 2014.
} 
quando o Conselho da Organização aprovou seu Estatuto. ${ }^{29}$ É, pois, esse órgão que irá decidir se o caso será ou não encaminhado para a Corte. Incorporada à Carta da OEA através do artigo 106, trabalha principalmente a partir de denúncias de violações de direitos humanos, causadas ou toleradas por Estados-membros.

Vale frisar que qualquer pessoa, grupo de pessoas ou ONG pode fazer a denúncia escrita perante a Comissão, ${ }^{30}$ que analisa e investiga as petições. Isto porque, a proteção dos direitos humanos não é considerada de interesse específico de um indivíduo e, portanto, direito subjetivo seu, mas sim interesse de toda a coletividade. Tenta-se, então, um acordo entre as partes e, se este acordo se mostrar inviável, o processo será encaminhado para a Corte, caso assim a Comissão decida.

A CIDH realiza seu trabalho com base em três pilares: (1) o Sistema de Petição Individual; (2) o monitoramento da situação dos direitos humanos nos Estados-membros, e (3) a atenção a linhas temáticas prioritárias. Segundo o próprio site da Organização dos Estados Americanos,

através dessa estrutura, a Comissão considera que, no contexto da proteção dos direitos de toda pessoa sob jurisdição dos Estados americanos, é fundamental dar atenção as populações, comunidades e grupos historicamente submetidos à discriminação. De forma complementar, outros conceitos formam seu trabalho: o princípio pro homine - segundo o qual a interpretação de uma norma deve ser feita da maneira mais favorável ao ser humano -, a necessidade de acesso à justiça, e a incorporação da perspectiva de gênero em todas suas atividades. ${ }^{31}$

Há, entretanto, alguns requisitos processuais para a aceitação da competência da Corte pela Comissão, como: o esgotamento dos recursos

\footnotetext{
${ }^{29}$ Comissão Interamericana de Direitos Humanos. In: Organização dos Estados Americanos democracia para a paz, segurança e desenvolvimento. Disponível em: http://www.oas.org/pt/sobre/comissao_direitos_humanos.asp. Acesso em: 24 out. 2014.

30 Convenção Interamericana de Direitos Humanos, artigo 44. Disponível em: http://www.pge.sp.gov.br/centrodeestudos/bibliotecavirtual/instrumentos/sanjose.htm. Acesso em 31 ago. 2014

${ }^{31} \mathrm{O}$ que é a CIDH. In: Organização dos Estados Americanos - democracia para a paz, segurança e desenvolvimento. Disponível em: http://www.oas.org/pt/cidh/mandato/que.asp. Acesso em: 6 jul. 2014.
} 
judiciais internos; um período de decadência de denúncia perante a Comissão até seis meses após a parte tomar conhecimento da última decisão nacional; e que não haja litispendência de outro processo internacional. ${ }^{32}$ Vale ressaltar, contudo, que tais requisitos não se aplicam se não existir, na legislação interna do Estado o qual se tratar, o devido processo legal para a proteção do direito ou direitos que se aleguem violados; bem como ter sido impedido o acesso ao recurso da jurisdição interna ou houver demora injustificada na decisão da lide. $^{33}$

Recebida a denúncia, o Secretário notifica sua existência aos juízes, ao Estado demandado, à Comissão, ao próprio denunciante e às vítimas, conforme o caso. $^{34}$ São as partes denunciadas (no caso, Estados que ratificaram a Convenção) que devem oferecer as questões preliminares, como por exemplo, a já mencionada do não-esgotamento de recursos internos, que nas palavras de Antônio A. Cançado Trindade "é de pura admissibilidade, a ser interposta pelo Estado demandado in limite litis, sem o que se presume sua renúncia tácita por parte do Estado demandado.”35

Na decisão, os juízes podem decidir pela reparação à violação. Os votos e argumentos jurídicos são notificados às partes e depois tornam-se públicos. As partes ainda podem solicitar a interpretação da decisão, caso existam dúvidas. ${ }^{36}$ Isto ocorre porque são as decisões que revelam a correta interpretação da Convenção, bem como, fazem o controle de convencionalidade - à semelhança do controle de constitucionalidade - das

32 Convenção Interamericana de Direitos Humanos, artigo 46. Disponível em: http://www.pge.sp.gov.br/centrodeestudos/bibliotecavirtual/instrumentos/sanjose.htm. Acesso em 24 out. 2014.

33 Convenção Interamericana de Direitos Humanos, artigo 47. Disponível em: http://www.pge.sp.gov.br/centrodeestudos/bibliotecavirtual/instrumentos/sanjose.htm. Acesso em 24 out. 2014.

${ }^{34}$ VARELLA, Marcelo Dias. Direito Internacional Público. 2 ed. São Paulo: Ed. Saraiva, 2010. p. 447.

${ }^{35}$ Ibid. p. 448.

36 Convenção Interamericana de direitos humanos, artigo 59. Disponível em: http://www.pge.sp.gov.br/centrodeestudos/bibliotecavirtual/instrumentos/sanjose.htm. Acesso em: 6 jul. 2014. 
legislações nacionais com a Convenção, que a priori, deveria ser realizado pelos Poderes dos próprios Estados-membros. ${ }^{37}$

A Corte Interamericana, como já mencionado, adota uma postura bastante precursora no mundo no que diz respeito à ampliação do conteúdo dos direitos humanos. No que cabe aos assuntos relacionados às normas cogentes, também não é diferente. Com um histórico de aplicação do domínio material de jus cogens na resolução de seus conflitos mais notório que das outras cortes internacionais, o "leading-case" do tema é o caso "Almonacid Arellano y otros versus Chile”, o qual será tratado a seguir.

\subsection{O caso "Almonacid Arellano y otros versus Chile"}

Com a sentença datada de 26 de setembro de 2006, o caso de Almonacid Arellano foi o "leading-case" no que diz respeito a impossibilidade das violações de jus cogens ficarem impunes através de leis de anistia. Ainda que a temática das leis de auto-anistia tenha sido anteriormente abordada no caso Barrios Altos vs. Peru, foi no caso aqui apresentado que a Corte travou uma fundamentação maior sobre a impossibilidade de anistia por ser matéria de jus cogens. Além disso, discutiu o que efetivamente faria parte do âmbito das normas imperativas (como é o caso dos crimes contra a humanidade), e deu um contributo mais amplo sobre a definição e utilização do termo, o qual permeia suas sentenças até hoje.

O pano de fundo histórico do presente caso, contudo, remonta à década de 1970, auge da ditadura chilena comandada por Augusto Pinochet, a qual tivera início em 11 de setembro de 1973, com o golpe militar que derrubara o então presidente Salvador Allende. Congregando as funções do Poder Executivo, Legislativo e exercendo forte influencia no Judiciário, Pinochet

\footnotetext{
${ }^{37}$ Sobre o assunto: BERNARDES, Marcia Nina. Sistema Interamericano de Direitos Humanos como Esfera Pública Transnacional: aspectos jurídicos e políticos da implementação de Decisões Internacionais. In. SUR. Revista Internacional de Direitos Humanos. v. 1, n. 1, jan 2004. São Paulo, 2004.
} 
além de comandar todo o exército, tão logo que assumiu o poder promulgou o Decreto Lei $\mathrm{n}^{\circ}$ 5, de 22 de setembro de 1973, o qual declarara estado de sítio.

Em outras palavras, era o estado de guerra, que iria justificar toda a repressão feita pelo novo governo às pessoas que o regime considerava como opositoras. Tal repressão foi caracterizada por uma prática massiva e sistemática de fuzilamentos, privações arbitrárias de liberdade em recintos à margem do escrutínio da lei, desaparições forçadas e demais violações de direitos humanos cometidas por agentes de Estado, muitas vezes assistidos por civis. Segundo o informe da Comissão da Verdade e Reconciliação do Chile, a repressão se aplicou em quase todas as regiões do país. ${ }^{38}$

A época mais violenta de todo o período repressivo, corresponde justamente ao início do governo, no qual destacadamente se deu a execução de figuras notórias no antigo regime, bem como o amedrontamento de pessoas que pudessem oferecer alguma ameaça, como: pessoas de esquerda, militantes comuns, chefes e dirigentes políticos, sindicais e estudantes - os quais foram inseridos em uma atuação de "limpeza". Havia, portanto, uma ampla margem de arbitrariedade no momento de selecionar as vítimas.

No que diz respeito às execuções forçadas, crime o qual aqui se trata, as mortes normalmente se davam à noite, à margem de qualquer processo criminal ou investigatório, eram fulminantes e em geral no mesmo momento da detenção. Algumas vezes, na presença da família da vítima.

No caso da execução extrajudicial de Almonacid Arellano, não fora diferente. Encontrado no dia 16 de setembro de 1973 por policiais na porta de sua casa (na qual já não estava mais morando por medida de segurança), fora morto a tiros, na presença de sua esposa, grávida de oito meses. No depoimento da mesma à Corte, ela informou que ainda fora impedida de lhe prestar socorro quando tentou se aproximar da vítima com seus dois filhos

\footnotetext{
${ }^{38}$ CORTE INTERAMERICANA DE DIREITOS HUMANOS. Caso Almonacid Arellano y otros vs. Chile. 2006. p. 28.
} 
pequenos. ${ }^{39}$ Almonacid Arellano fora jogado em um caminhão e levado ao hospital pelos próprios policiais que lhe atiraram. Morreu no dia seguinte.

Ainda segundo Elvira Gomez, esposa de Almonacid, no mesmo momento em que atiraram contra seu marido, sua placenta se desprendeu, causando-lhe a morte também do feto de oito meses. Ademais, após a morte do marido, lhe passaram a vigiar todos os dias e seus irmãos foram impedidos de trabalhar pelo governo. ${ }^{40}$

A primeira investigação do caso teve início em 3 de outubro de 1973 e fora arquivada um mês depois. A Corte de Apelação do Chile ainda chegou a revogar o arquivamento, até que o confirmou em 4 de setembro de 1974.

Foi apenas quando o regime de Augusto Pinochet chegou ao fim em 1990, com a consequente reabertura democrática, que Elvira Gomez Olivares, apresentou nova queixa criminal e solicitou a reabertura da causa, em 1992. Por meio de resoluções, o juiz da causa se declarou incompetente para julgá-la e a remeteu à justiça militar. ${ }^{41}$ Tendo a Corte de Apelações revogado a decisão de incompetência, o juízo de origem arquivou definitivamente o processo, em aplicação do Decreto-lei n 2.191.

O Decreto-lei ${ }^{0} 2.191$ muito se assemelha a Lei de Anistia brasileira, pelo qual o governo de Pinochet que regia o país em 1978 concedeu anistia a todas as pessoas que na qualidade de autores ou partícipes, cometeram crimes durante a situação de estado de sítio (11 de setembro de 1973 a 10 de março de 1978), exceto por crimes como infanticídio, parricídio, tráfico de drogas, corrupção de menores, estupro, incêndio, incesto, fraude e outros "abusos

\footnotetext{
39 Declaração de Elvira Gómez Olivares, esposa de Luis Alfredo Almonacid Arellano. (Corte Interamericana de Direitos Humanos. Caso Almonacid Arellano y otros vs. Chile. 2006. p. 20.

${ }^{40}$ Declaração de Elvira Gómez Olivares, esposa de Luis Alfredo Almonacid Arellano. (Corte Interamericana de Direitos Humanos. Caso Almonacid Arellano y otros vs. Chile. 2006. p. 20.

${ }^{41}$ CORTE INTERAMERICANA DE DIREITOS HUMANOS. Caso Almonacid Arellano y otros vs. Chile. 2006. p. 31.
} 
desonestos". ${ }^{42} \mathrm{Na}$ prática, era um decreto que anistiava os crimes praticados pelos agentes de Estado, tendo em vista que mesmo os que tinham cometido crimes "políticos" ao lado da esquerda em razão do novo governo, se encontraram excluídos da anistia pelo artigo $\mathrm{n}^{\circ} 4^{\circ}$ do mesmo Decreto-lei. ${ }^{43}$

Ainda aberto e arquivado o processo mais algumas vezes, foi finalmente remetido à justiça militar, e a decisão desta, em 1997 (repare-se, já 5 anos após o início da ação na justiça comum), foi no sentido de que a anistia é uma causa objetiva de extinção de responsabilidade criminal, uma lei de direito público que visa o interesse geral da coletividade. Seus efeitos, se produziriam então de pleno direito a partir do momento por ela estabelecido, de forma que, caberia aos juízes apenas aplica-la. Uma vez que o ilícito penal de Almonacid Arellano ocorrera no interregno de tempo coberto pela anistia, o Decreto-lei teria plena eficácia e corresponderia aos juízes apenas declará-la, arquivando definitivamente o processo. ${ }^{44}$

A Corte Marcial (última instância militar do Chile) ainda consignou a impossibilidade de sustentar que instrumentos internacionais, como o Pacto de São José da Costa Rica, fossem idôneos para afastar a eficácia do Decreto-lei $\mathrm{n}^{\circ}$ 2.191. Segundo a Corte Marcial, uma vez que o Pacto teria sido incorporado ao direito chileno em 29 de abril de 1989, não poderia retroagir sua aplicação afetando o princípio da irretroatividade da lei penal. ${ }^{45}$

Uma ministra da Corte Marcial, contudo, não esteve de acordo com o resultado proposto pela maioria e considerou que

42 CHILE. Decreto-lei $\mathrm{n}^{\circ} 2.191$ de 18 de abril de 1978. Disponível em : http://www.archivochile.com/Poder_Dominante/pod_publi_parl/PDparlamento0005.pdf. Acesso em 21 ago 2014.

43 “Tampoco serán favorecidas com la aplicación del articulo $1^{\circ}$, las personas que aparecierem responsables, sea em calidad de autores, cómplices o encobridores, de los hechos que se investigan en processo rol No 192-78 del Juzgado Militar de Santiago, Fiscalia Ad Hoc.” (CHILE. Decreto-lei no 2.191 de 18 de abril de 1978).

${ }^{44}$ CORTE INTERAMERICANA DE DIREITOS HUMANOS. Caso Almonacid Arellano y otros vs. Chile. 2006. p. 35 apud Sentença da Corte Marcial do Chile de 25 de março de 1998 (Expediente de anexos da demanda, anexo 3, p. 42).

${ }^{45}$ CORTE INTERAMERICANA DE DIREITOS HUMANOS. Caso Almonacid Arellano y otros vs. Chile. 2006. p. 35 apud Sentença da Corte Marcial do Chile de 25 de março de 1998 (Expediente de anexos da demanda, anexo 3, p. 44). 
el homicidio del señor Almonacid Arellano se perpetró en una época en que imperaba en el país un estado de guerra interna, y que tal acto, atendidas las circunstancias y modalidad de su comisión, [...] es una de las acciones prohibidas por el artículo 3 [común] de los Convenios de Ginebra. Asimismo, el artículo 52 de los Convenios de Ginebra hace claramente imprescriptible e inadmistiable los crímenes de guerra. ${ }^{46}$

Contudo, fora voto vencido e mesmo a Suprema Corte do Chile, ao ser provocada por Elvira Gomes Olivares, decidiu ser o recurso extemporâneo e ordenou o seu arquivamento. O Sistema Interamericano de Direitos Humanos se tornara, por fim, a última alternativa para os familiares de Almonacid.

Uma vez então corroborado que a denegação de justiça por parte do Estado do Chile se deveu a aplicação do Decreto-lei de auto-anistia, expedido pela ditadura militar como um auto perdão em benefício de seus membros, ${ }^{47} \mathrm{a}$ primeira consideração da Corte Interamericana, na parte dispositiva da sentença que julgou o caso de Almonacid, fora decidir sobre a violação aos artigos 1.1, 8.1 e 25 do Pacto de São José da Costa Rica.

Reza o artigo 1.1 da Convenção Interamericana de Direitos Humanos:

Os Estados-partes nesta Convenção comprometem-se a respeitar os direitos e liberdades nela reconhecidos e a garantir seu livre e pleno exercício a toda pessoa que esteja sujeita à sua jurisdição, sem discriminação alguma, por motivo de raça, cor, sexo, idioma, religião, opiniões políticas ou de qualquer outra natureza, origem nacional ou social, posição econômica, nascimento ou qualquer outra condição social. ${ }^{48}$

Por sua vez, os artigos 8.1 e 25, que tratam das garantias e da proteção judicial, respectivamente, preveem que :

8.1.Toda pessoa terá o direito de ser ouvida, com as devidas garantias e dentro de um prazo razoável, por um juiz ou Tribunal competente, independente e imparcial, estabelecido anteriormente por lei, na apuração de qualquer

\footnotetext{
${ }^{46}$ CORTE INTERAMERICANA DE DIREITOS HUMANOS. Caso Almonacid Arellano y otros vs. Chile. 2006. p. 35 apud Voto dissidente da Ministra Morales na Sentença da Corte Marcial do Chile de 25 de março de 1998 (Expediente de anexos da demanda, anexo 3, p. 44-45).

${ }^{47}$ CORTE INTERAMERICANA DE DIREITOS HUMANOS. Caso Almonacid Arellano y otros vs. Chile. 2006. p. 41.

48 Convenção Interamericana de direitos humanos, artigo 1.1. Disponível em: http://www.pge.sp.gov.br/centrodeestudos/bibliotecavirtual/instrumentos/sanjose.htm. Acesso em: 7 set. 2014.
} 
acusação penal formulada contra ela, ou na determinação de seus direitos e obrigações de caráter civil, trabalhista, fiscal ou de qualquer outra natureza. ${ }^{49}$

25. Toda pessoa tem direito a um recurso simples e rápido ou a qualquer outro recurso efetivo, perante os juízes ou tribunais competentes, que a proteja contra atos que violem seus direitos fundamentais reconhecidos pela Constituição, pela lei ou pela presente Convenção, mesmo quando tal violação seja cometida por pessoas que estejam atuando no exercício de suas funções oficiais. ${ }^{50}$

E para decidir se houve a violação ou não destes artigos, a Corte subdividiu a questão em quatro partes: (1) qualificar se o homicídio de Almonacid Arellano constitui um crime contra a humanidade e, portanto, faz parte da proibição do conteúdo material de jus cogens; (2) caso seja considerado que sim, decidir se tal crime pode ou não ser anistiado; (3) caso seja verificado que tal crime jamais poderia ser anistiado, analisar se o Decreto-lei $n^{0} 2.191$ anistia ou não este crime e se o Estado violou ou não a Convenção Americana ao manter vigente esta norma; (4) e finalmente, analisar se a aplicação da norma por parte das autoridades judiciais no presente caso substancia uma violação dos direitos consagrados nos artigos 8.1 e 25 da Convenção Americana.

Para analisar se o homicídio de Almonacid constitui ou não um crime contra a humanidade, a Corte decidiu verificar se na data em que o fato ocorreu, era considerado como tal. Para isso, fez uma digressão à ideia de que a noção de crime contra a humanidade, embora tenha aparecido como termo pela primeira vez através dos governos da França, do Reino Unido e da Rússia para denunciar o massacre de armênios na Turquia, fora codificado pela primeira vez no artigo 6 do Estatuto do Tribunal de Nuremberg, em 1945. Pouco depois, a Lei do Conselho de Controle dos Aliados $n^{0} 10$ também

49 Convenção Interamericana de direitos humanos, artigo 8.1. Disponível em: http://www.pge.sp.gov.br/centrodeestudos/bibliotecavirtual/instrumentos/sanjose.htm. Acesso em: 7 set. 2014.

50 Convenção Interamericana de direitos humanos, artigo 25. Disponível em: http://www.pge.sp.gov.br/centrodeestudos/bibliotecavirtual/instrumentos/sanjose.htm. Acesso em: 7 set. 2014. 
consagrou o assassinato como um crime contra a humanidade em seu artigo $2^{\text {o }}{ }^{51}$

A Corte reconheceu, então, que o Estatuto de Nuremberg teve um papel significativo no estabelecimento dos elementos que caracterizam um crime de lesa humanidade. O Estatuto proporcionou a primeira articulação dos seus elementos, os quais se mantiveram basicamente os mesmos desde sua concepção até a morte do senhor Almonacid Arellano. ${ }^{52}$

Com base nisso, a Corte reconheceu que os crimes contra a humanidade incluem a prática de atos desumanos, como o assassinato cometido no contexto de um ataque generalizado ou sistemático contra uma população civil. Basta que apenas um ato ilícito como o antes mencionado, seja cometido dentro do contexto descrito, para que se produza um crime de lesa humanidade. E todos esses elementos já estavam definidos juridicamente quando Almonacid Arellano fora executado. ${ }^{53}$

Além disso, o Estatuto de Nuremberg indicou que era a "expressão do Direito Internacional existente no momento da sua criação e era em si mesmo também uma construção ao Direito Internacional”. ${ }^{54}$ Deste modo, reconheceu a existência de um costume (com senso de obrigação legal) como expressão do Direito Internacional que já proibia esses crimes.

Estas foram, então, as evidencias encontradas pela Corte Interamericana para apontar que em 1973, ano da morte de Almonacid Arellano, o assassinato executado em um contexto generalizado ou sistemático, já era considerado um

\footnotetext{
${ }^{51}$ CORTE INTERAMERICANA DE DIREITOS HUMANOS. Caso Almonacid Arellano y otros vs. Chile. 2006. p. 44.

${ }^{52}$ Ibid. p. 44.

${ }^{53}$ No mesmo sentido se pronunciou o Tribunal Penal Internacional para a ex Iugoslávia, no caso "Prosecutor v. Dusko Tadic" ao considerar que "um só ato cometido por um perpetrador no contexto de um ataque generalizado ou sistemático contra a população civil traz consigo responsabilidade penal individual, e o perpetrador não necessita cometer numerosas ofensas para ser considerado responsável.” (CORTE INTERAMERICANA DE DIREITOS HUMANOS. Caso Almonacid Arellano y otros vs. Chile. 2006. P. 44.)

${ }^{54}$ Trial of the Major War Criminals before the International Military Tribunal. Nuremberg, 1947. p. 218. In: Library of Congress. Disponível em: http://www.loc.gov/rr/frd/Military_Law/pdf/NT_VolI.pdf. Acesso em: 24 out. 2014.
} 
crime contra a humanidade, e também uma violação à norma imperativa de direito internacional, ${ }^{55}$ ponto que mais interessa ao presente trabalho. Nas palavras da Corte,

dicha prohibición de cometer crímenes de lesa humanidad es una norma de ius cogens, y la penalización de estos crímenes es obligatoria conforme al derecho internacional general. $^{56}$

Por isso é que, dando continuidade às considerações da Corte, ainda que a auto-anistia tenha sido concedida antes da ratificação da Convenção Americana pelo Estado do Chile, de acordo com o Direito Internacional da época, já não era possível anistiar crimes desta natureza - que violassem normas imperativas internacionais. Desde o Tribunal de Nuremberg e a primeiras reuniões da Assembleia Geral das Nações Unidas ${ }^{57}$, tem sido sustentado pela comunidade dos Estados que os responsáveis por crimes contra a humanidade - por terem como vítimas não só o indivíduo, mas toda a humanidade - não podem deixar de serem sancionados. E leis de anistia não são capazes de quebrar esta regra.

Ora, se já ficou consignado desde 1969 (através da Convenção de Viena sobre o Direito dos Tratados) que nem tratados seriam capazes de afastar as normas imperativas internacionais, não há sentido em uma lei interna o ser. Esta foi também a posição do Secretário Geral das Nações Unidas em seu informe sobre o estabelecimento do Tribunal Especial para Serra Leoa, ao

\footnotetext{
${ }^{55}$ Tal entendimento também está de acordo com os artigos 5 e 3 dos Estatutos dos Tribunais Internacionais Penais para a ex Iugoslavia e Ruanda, os quais reafirmam que o assassinato sistemático constitui uma grave violação ao direito internacional, bem como, corrobora com o artigo 7 do Estatuto de Roma, que será analisado a seguir.

${ }^{56}$ CORTE INTERAMERICANA DE DIREITOS HUMANOS. Caso Almonacid Arellano y otros vs. Chile. 2006. P. 46.

${ }^{57}$ Na segunda resolução, a Assembleia Geral afirmou que: “Os crimes de guerra e os crimes de lesa humanidade, onde quer que tenham ocorrido e qualquer que seja a data em que tenham sido cometidos, serão objeto de uma investigação, e as pessoas contra quem existam provas de culpabilidade no cometimento de tais crimes serão buscadas, detidas, julgadas e, em caso de serem declaras culpadas, castigadas. (...) Os Estados não adotarão medidas de outra índole que possam frustrar as obrigações internacionais que hajam contraído com respeito a identificação, detenção, extradição e castigo dos culpados dos crimes de guerra e crimes de lesa humanidade.” (O.N.U. Princípios de cooperação internacional na identificação, detenção, extradição e castigo dos culpados dos crimes de guerra, ou crimes de lesa humanidade adotados pela Assembleia Geral das Nações Unidas em sua resolução XXVII.)
} 
afirmar que ainda que leis de anistia sejam promulgadas com o propósito de paz e reconciliação em um período pós-guerra, as Nações Unidas matem sistematicamente a posição segundo a qual a anistia não pode ser concedida a respeito de crimes internacionais como genocídio, crimes contra a humanidade ou às infrações graves de direito internacional humanitário. ${ }^{58}$

Ademais, a Corte considerou que a obrigação de julgar e declarar culpados os agentes perpetradores de crimes contra a humanidade, se depreende não só das regras gerais do Direito Internacional, mas também da própria Convenção Americana, devido a obrigação de organizar o seu aparato legislativo e judiciário no sentido de assegurar juridicamente o pleno exercício dos direitos humanos. À luz do artigo $2^{\circ}$ da Convenção, tal adequação implica na adoção de medidas em duas vertentes, a saber: (1) a supressão de normas e práticas que contenham violações às garantias previstas na Convenção; e (2) a expedição de normas e práticas de atos condizentes com a efetiva observância de tais garantias. ${ }^{59}$

O Estado do Chile violou, portanto, não só o artigo $1^{\circ}$ do Pacto de São José, que trata sobre a garantia do Estado do livre exercício dos direitos a todos que estão sob a sua jurisdição, mas também não cumpriu com o seu dever de evitar e combater a impunidade, diversas vezes assinalado pela Corte Interamericana. $^{60}$

Uma vez considerado ser inadmissível disposições de anistia, de prescrição ou qualquer outra excludente de responsabilidade que pretendam impedir a investigação e a sanção dos responsáveis por violações graves de direitos humanos tais como a tortura, a execução sumária e as desaparições forçadas - todas elas proibidas por violarem matérias do domínio do jus cogens

\footnotetext{
${ }^{58}$ CORTE INTERAMERICANA DE DIREITOS HUMANOS. Caso Almonacid Arellano y otros vs. Chile. 2006. P. 49. apud O.N.U., Informe do Secretário Geral sobre o estabelecimento de um Tribunal para Serra Leoa. S/2000/915 de 4 de outubro de 2000, pár. 22.

${ }^{59}$ CORTE INTERAMERICANA DE DIREITOS HUMANOS. Caso Almonacid Arellano y otros vs. Chile. 2006. p. 51.

${ }^{60}$ Vide sentenças da Corte Interamericana de Direitos Humanos em casos brasileiros, como "Ximenes Lopez vs. Brasil” ou "Gomes Lund y otros (Guerrilha do Araguaia) vs. Brasil”.
} 
-, a existência de uma dessas disposições em um ordenamento jurídico, conduzindo à impossibilidade de defesa das vítimas e a perpetuação de um crime contra a humanidade, constitui por si só uma violação da Convenção Americana e gera responsabilidade internacional do Estado. Chega-se então à resposta ao quesito número 3 antes apontado: segundo a Corte, o Estado do Chile ao manter tal norma vigente no ordenamento mesmo após a ratificação do tratado, violou o Pacto de São José. Deste modo, o Decreto-lei n ${ }^{\circ} 2.191$ careceria de efeitos jurídicos e não poderia seguir representando um obstáculo às investigações dos fatos que constituem o caso, nem como ao castigo dos responsáveis. ${ }^{61}$

Por fim, a Corte consignou que o cumprimento por parte de agentes de Estado de uma lei violadora da Convenção, também provoca a responsabilidade internacional desse Estado. Isso porque, no pensamento da Corte, quando um Estado ratifica um tratado internacional, também estão submetidos a ele seus juízes, como parte do aparato estatal. ${ }^{62}$ À vista disso, como já aduzido, estes mesmos juízes deveriam estar aptos a fazer não só o controle de constitucionalidade com as suas Constituições, mas também, o controle de convencionalidade entre as normas jurídicas internas que aplicam nos casos concretos e a Convenção Americana - levando em consideração não só o tratado, mas também as interpretações dadas pela Corte. ${ }^{63}$

Isto posto, ao não fazer tal controle e aplicar o Decreto-lei ao invés da Convenção, o Estado do Chile violou o artigo 1.1 do Pacto de São José, já assinalado, mas também os artigos 8.1 e 25 , que tratam das garantias e da proteção judicial. Ademais, outorgou competência à jurisdição militar sobre

${ }^{61}$ CORTE INTERAMERICANA DE DIREITOS HUMANOS. Caso Almonacid Arellano y otros vs. Chile. 2006. p. 52.

${ }^{62}$ Por isso a crítica de Marcia Nina Bernardes ao falar sobre a necessidade dos juízes brasileiros aprenderem e entenderem mais sobre o Sistema Interamericano, e sobre os próprios direitos humanos. (BERNARDES, Marcia Nina. Sistema Interamericano de Direitos Humanos como Esfera Pública Transnacional: aspectos jurídicos e políticos da implementação de Decisões Internacionais. In. SUR. Revista Internacional de Direitos Humanos. v. 1, n. 1, jan 2004. São Paulo, 2004.)

${ }^{63}$ CORTE INTERAMERICANA DE DIREITOS HUMANOS. Caso Almonacid Arellano y otros vs. Chile. 2006. p. 53. 
um assunto que deveria conhecer a justiça ordinária, afetando o princípio do juiz natural e o devido processo legal, o qual, se encontra intimamente ligado ao próprio acesso a justiça. Em resumo, nas palavras da Corte:

El Tribunal, como conclusión de todo lo señalado en esta sección A), considera que el asesinato del señor Almonacid Arellano formó parte de una política de Estado de represión a sectores de la sociedad civil, y representa sólo un ejemplo del gran conjunto de conductas ilícitas similares que se produjeron durante esa época. El ilícito cometido en contra del señor Almonacid Arellano no puede amnistiarse conforme a las reglas básicas del derecho internacional, puesto que constituye un crimen de lesa humanidad. El Estado incumplió su obligación de adecuar su derecho interno a efectos de garantizar los derechos establecidos en la Convención Americana, porque mantuvo y mantiene en vigencia el Decreto Ley No. 2.191, el que no excluye a los crímenes de lesa humanidad de la amnistía general que otorga. Finalmente, el Estado violó el derecho a las garantías judiciales y a la protección judicial, e incumplió con su deber de garantía, en perjuicio de los familiares del señor Almonacid Arellano, porque aplicó el Decreto Ley No. 2.191 al presente caso. ${ }^{64}$

Tendo sido expostas as violações acima, a consequência necessária da responsabilidade internacional é a reparação do dano causado a ser feita pelo Estado do Chile. É o que estabelece, pois, o artigo 63.1 da Convenção Americana, in verbis:

Quando decidir que houve violação de um direito ou liberdade protegidos nesta Convenção, a Corte determinará que se assegure ao prejudicado o gozo do seu direito ou liberdade violados. Determinará também, se isso for procedente, que sejam reparadas as consequências da medida ou situação que haja configurado a violação desses direitos, bem como o pagamento de indenização justa à parte lesada. ${ }^{65}$

Desta forma, a Corte decidiu no sentido de determinar - para ser possível a restituição integral (ou a menos parcial) das violações declaradas na sentença -, em primeiro lugar, a adequação do direito interno chileno à Convenção Americana.

\footnotetext{
${ }^{64}$ CORTE INTERAMERICANA DE DIREITOS HUMANOS. Caso Almonacid Arellano y otros vs. Chile. 2006. p. 54.

65 Convenção Interamericana de Direitos Humanos, artigo 63.1. Disponível em: http://www.pge.sp.gov.br/centrodeestudos/bibliotecavirtual/instrumentos/sanjose.htm. Acesso em: 13 jul. 2014.
} 
Em segundo, deve o Estado, pois, remeter o expediente à justiça ordinária (para que dentro de um processo penal justo se identifique e sancione todos os responsáveis pela morte de Almonacid Arellano), bem como assegurar que o Decreto-lei ${ }^{\circ} 2.191$ não siga representando um obstáculo para tal investigação e sanção, nem como para investigação ou julgamento de nenhuma violação ocorrida nos mesmos moldes no Estado do Chile. ${ }^{66}$ Pois que, nas palavras da Corte, ainda que informes de conciliação mencionem e resumam o que ocorreu no Chile nos tempos da ditadura, "não pode substituir a obrigação do Estado lograr a verdade através de seus processos judiciais",67, de forma que qualquer argumento de irretroatividade da lei penal, princípio de bis in idem (quando o processo não for imparcial) ou até mesmo prescrição, não servem para justificar as graves violações a direitos humanos perpetradas e que estão até hoje sem resposta. Parafraseando a Corte:

Los crímenes de lesa humanidad van más allá de lo tolerable por la comunidad internacional y ofenden a la humanidad toda. El daño que tales crímenes ocasionan permanece vigente para la sociedad nacional y para la comunidad internacional, las que exigen la investigación y el castigo de los responsables. En este sentido, la Convención sobre la imprescriptibilidad de los crímenes de guerra y de los crímenes de lesa humanidad claramente afirmó que tales ilícitos internacionales "son imprescriptibles, cualquiera que sea la fecha en que se hayan cometido". ${ }^{6}$

Em outras palavras, mesmo que o Estado do Chile não tenha ratificado a Convenção Americana à época da execução extrajudicial, a Corte considera que a imprescritibilidade dos crimes contra a humanidade surge como categoria de norma de Direito Internacional geral - jus cogens -, que não nasce na Convenção, e sim, que está reconhecida nela. Consequentemente, o Chile não pode deixar de cumprir esta norma imperativa. ${ }^{69}$

\footnotetext{
${ }^{66}$ CORTE INTERAMERICANA DE DIREITOS HUMANOS. Caso Almonacid Arellano y otros vs. Chile. 2006. p. 59.

${ }^{67}$ Ibid. p. 60.

${ }^{68}$ Ibid. p. 60.

${ }^{69}$ Ibid. p. 61.
} 
Por isto é que o Estado deve ser capaz de assegurar que a família de Almonacid Arellano tenha pleno acesso e capacidade de atuar em todas as etapas e instancias das investigações, de acordo com a Convenção Americana e o Direito Internacional dos Direitos Humanos. Bem como, os resultados das investigações devem ser publicamente divulgados pelo Estado, de maneira tal que a sociedade chilena possa conhecer a real verdade acerca dos fatos. ${ }^{70}$

Ademais, a Corte condenou o Estado ao pagamento das custas e gastos processuais empreendidos pela família de Almonacid, e a publicar em seu Diário Oficial e outro diário de grande circulação nacional, o capítulo relativo aos fatos provados da sentença e a parte resolutiva da mesma, como uma forma per se de reparação.

Vale ainda, para o presente trabalho, algumas considerações a serem feitas a respeito do voto arrazoado de Antônio A. Cançado Trindade, por ter o jurista se estendido ainda mais sobre o tema das normas imperativas. $\mathrm{O}$ voto trata da (1) falta de validez jurídica das leis de auto-anistia; (2) da denegação e obstrução de justiça por elas causadas; (3) da ampliação do conteúdo material de jus cogens; (4) e da conceituação dos crimes contra a humanidade em confluência entre o Direito Internacional dos Direitos Humanos e o Direito Penal Internacional.

No que diz respeito ao primeiro ponto, já ficou mais do que consignado que leis de anistia que pretendam impedir a investigação e sanção dos responsáveis por graves violações a direitos humanos carecem de efeitos

\footnotetext{
${ }^{70}$ CORTE INTERAMERICANA DE DIREITOS HUMANOS. Caso Almonacid Arellano y otros vs. Chile. 2006. P. 60. apud CORTE INTERAMERICANA DE DIREITOS HUMANOS. Caso Montero Arangurem y otros, párr. 139; Caso Baldeón Garcia, párr. 199; e Caso de la Mascre de Pueblo Bello, párr. 267.
} 
jurídicos, ${ }^{71}$ porque o perdão não pode ser imposto e sim, concedido espontaneamente pelas próprias vítimas. ${ }^{72}$

Mas na medida em que impendem a realização de justiça por crimes como genocídio e contra a humanidade, as auto-anistias seriam também violadoras do jus cogens:

Al llevar la Corte a declarar, en los términos del reconocimiento de responsabilidad internacional efectuado por el Estado demandado, las violaciones de los derechos a la vida y a la integridad personal, - dichas leyes afectan derechos inderogables - el minimum universalmente reconocido, - que recaen en el ámbito del jus cogens" ${ }^{173}$

E quando uma lei desta natureza leva ao encobrimento, por exemplo, da prática sistemática de detenções ilegais ou arbitrárias, sequestros, torturas ou desaparições forçadas - cuja proibição recai no domínio de jus cogens -, na opinião de Cançado Trindade, torna a responsabilidade do Estado ainda maior, haja vista que as proibições de jus cogens não dependem do consentimento deste, mas sim de toda a comunidade internacional.

Outrossim, no que diz respeito ao conteúdo material de jus cogens levantado pelo jurista, o acesso a justiça também pertenceria a este domínio. A razão principal disso seria porque "es por el libre y pleno ejercicio del derecho de petición individual que los derechos consagrados en los tratados de derechos humanos se han tornado efectivos.” ${ }^{74}$

Seria uma espécie do que Hannah Arendt chamara do "direito a ter direitos"75, haja vista que o "direito a ser sujeito de direitos" só é respeitado

\footnotetext{
${ }^{71}$ Vide a sentença do caso Barrios Altos versus Peru, julgado pela Corte Interamericana de Direitos Humanos, que se tornou mudialmente conhecida por ser a primeira vez que um tribunal internacional determinou que leis de auto-anistia carecem de efeitos jurídicos.

72 Voto arrazoado de Antônio Augusto Augusto Cançado Trindade, p. 2. (CORTE INTERAMERICANA DE DIREITOS HUMANOS. Almonacid Arellano y otros vs. Chile. 2006).

${ }^{73}$ CORTE INTERAMERICANA DE DIREITOS HUMANOS. Caso Almonacid Arellano y otros vs. Chile, 2006.

${ }^{74}$ TRINDADE, Antonio A. Cançado. La ampliación del contenido material del ius cogens. XXXV Curso de Derecho Internacional Organizado por el Comité Jurídico Interamericano - 2008, Washington D.C., Secretaría General de la OEA, 2009. p. 11.

${ }^{75}$ LAFER, Celso. A reconstrução dos direitos humanos: um diálogo com o pensamento de Hannah Arendt. São Paulo: Companhia das Letras, 1988. p. 39.
} 
através do acesso a um ordenamento jurídico que efetivamente salvaguarde os direitos inerentes a pessoa humana. Por esta razão é que seria uma norma imperativa: o acesso a justiça muitas vezes é o único meio disponível para fazer valer os direitos humanos - e se toda a comunidade de Estados concorda que determinados direitos são normas cogentes, o que lhes seja apto a garantir também o deve ser.

Por fim, o jurista termina seu voto fazendo uma consideração sobre os crimes contra a humanidade, na medida em que para ele, sua tipificação é uma grande conquista por refletirem a necessária condenação de violações graves e sistemáticas de direitos fundamentais e inderrogáveis. Ou seja, de violações de jus cogens, e da não aplicabilidade em casos de sua ocorrência dos chamados "statues of limitations", próprios dos sistemas jurídicos nacionais. ${ }^{76}$

Neste sentido, a Corte Interamericana vem incorporando o entendimento de que um único ato gravemente violador dos direitos humanos pode constituir um crime contra a humanidade, se cometido em um contexto de uma prática sistemática. Por suposto, um único ato, pode também ser violador de uma norma cogente internacional.

76 Voto arrazoado de Antônio Augusto Augusto Cançado Trindade, p. 8. (CORTE INTERAMERICANA DE DIREITOS HUMANOS. Caso Almonacid Arellano y otros vs. Chile. 2006) apud CORTE INTERAMERICANA DE DIREITOS HUMANOS. Caso Goiburú y otros vs. Paraguai. 2006. 


\section{CAPÍTULO 3 - O JUS COGENS À LUZ DA JURISDIÇÃO UNIVERSAL E DA RESPONSABILIDADE INTERNACIONAL DO INDIVÍDUO}

\subsection{O Estatuto de Roma e o Tribunal Penal Internacional}

Se a nível regional, a Corte Interamericana de Direitos Humanos já consignou que os crimes contra a humanidade são proibições do domínio do jus cogens, o Estatuto de Roma do Tribunal Penal Internacional, surgiu, a plano global, para aumentar o rol dessas proibições, incluindo em seu texto outras três categorias de crimes de maior gravidade, que afetam a comunidade internacional em seu conjunto e que, por isso mesmo, não cometê-los é considerado norma imperativa. A saber: o crime de genocídio, os crimes de agressão e os crimes de guerra, além dos crimes contra a humanidade.

Além disso, a criação do Tribunal Penal Internacional (TPI), por meio do Estatuto de Roma de 1998, efetivamente impulsionou a teoria da responsabilidade penal internacional dos indivíduos, haja vista que fora o primeiro tribunal permanente no qual se previu punição individual àqueles praticantes dos ilícitos elencados no Estatuto e assim já considerados pelo Direito Internacional.

No início da década de 1990, por deliberação do Conselho de Segurança das Nações Unidas, foram criados dois tribunais internacionais de caráter temporário para julgar pessoas que cometeram crimes, à semelhança do que ocorrera com o Tribunal de Nuremberg: um instituído para julgar as atrocidades praticadas no território da antiga Iugoslávia por Slobodan Milosevic, e outro para julgar as inúmeras violações de direitos de idêntica gravidade perpetrados em Ruanda. Porém, a grande mácula das Nações Unidas se voltava para a impossibilidade do Conselho de Segurança criar tribunais com competência para julgar e punir eventuais crimes cometidos por nacionais 
dos seus Estados-membros com assento permanente ${ }^{77}$, além de ter de lidar com as críticas sobre a ilegitimidade desses chamados "tribunais de exceção"78 tribunais criados para conflitos específicos, não condizentes com o Estado Democrático de Direito e que não respeitariam princípios como os da reserva legal e da irretroatividade da lei penal.

Daí o grande motivo pelo qual a necessidade avultante de criação e estabelecimento efetivo de uma corte penal internacional permanente, universal e imparcial, instruída para processar os acusados de cometer os mais graves crimes, não permitia postergar a questão. ${ }^{79} \mathrm{~A}$ partir daí, é que pode ser compreendido o anseio generalizado pela criação de uma Justiça Penal Internacional, que viu na criação do TPI, o instrumento apto a dignificar e fortalecer a proteção internacional dos direitos humanos em plano global.

Tal instrumento, fora aprovado em 17 de julho de 1998, em Roma, na Conferência Diplomática de Plenipotenciários das Nações Unidas. O oficialmente chamado "Estatuto de Roma do Tribunal Penal Internacional" teve por finalidade constituir o primeiro tribunal internacional com jurisdição criminal permanente, com sede em Haia, na Holanda. Foi aprovado por 120 Estados contra apenas 7 votos contrários - China, Estados Unidos, Iêmen, Iraque, Israel, Líbia e Qatar - e 21 abstenções. Não obstante a sua posição original, os Estados Unidos e Israel, levando em consideração a má repercussão internacional ocasionada por suas posições, acabaram assinando o Estatuto em 31 de dezembro de $2000 .^{80}$ Todavia, a ratificação do Estatuto, por essas mesmas potencias, tornou-se praticamente fora de cogitação após os atentados terroristas de 11 de setembro de 2001 em Nova York e Washington, bem como após as operações de guerra subsequentes no Afeganistão e na

\footnotetext{
${ }^{77}$ MAZZUOLI, Valerio de Oliveira. Curso de Direito Internacional Público. 5 ed. rev., atual., e ampl. São Paulo: Editora Revista dos Tribunais, 2011. p. 945.

${ }^{78}$ Sobre o assunto: GOUVEIA, Jorge Barcelar. Direito Internacional Penal - Uma perspectiva dogmático-jurídica. Portugal: Livraria Almedina, 2008.

${ }^{79} \mathrm{O}$ caso do ex-general nazista Adolf Eichmann, capturado pelo serviço de inteligência israelense e julgado em Jerusalém, também contribuiu para colocar o assunto em pauta.

${ }^{80}$ MAZZUOLI, Valerio de Oliveira. Op. cit., p. 947.
} 
Palestina, em flagrante violação à normativa internacional. Assim foi que em 6 de maio de 2002 e em 28 de agosto do mesmo ano, Estados Unidos e Israel, respectivamente, notificaram o Secretário-Geral das Nações Unidas de que não tinham a intenção de tornarem-se partes no respectivo tratado. ${ }^{81}$

O Estatuto do TPI entrou em vigor em $1^{\circ}$ de julho de 2002, com uma proposta que muito se assemelhou ao Tribunal de Nuremberg. Isto porque, o seu funcionamento independe de qualquer tipo de ingerência externa, podendo inclusive demandar nacionais de Estados não-partes no Estatuto, haja vista a gravidade dos delitos os quais trata, que estão amparados pelo princípio da jurisdição universal do Tribunal. Em síntese, segundo tal princípio, há a não aplicabilidade das limitações legais quando se trata de crimes que afetam a própria humanidade, transcendendo, inclusive, o tradicional princípio da territorialidade da lei penal.

Basta que um dos crimes previstos pelo Estatuto seja cometido e que o Estado no qual ocorrera não dê conta da sua reparação. Tal foi exatamente o que ocorreu em julho de 2008, quando se formulou um pedido de prisão cautelar contra o ditador do Sudão (país não signatário do Estatuto), Omar AlBashir, acusado de genocídio, crimes de guerra e crimes contra a humanidade, tendo a ONU estimado em 300 mil o número de mortos. ${ }^{82}$

Em outras palavras, não obstante o Estatuto de Roma ter exigido ratificações dos Estados para ter entrado em vigor, dotou a Corte Penal Internacional de poderes tais que a possibilita exigir o cumprimento de uma ordem de prisão contra pessoa (como no caso do Sudão, um Presidente da República em exercício) que se encontra em território de Estado não signatário do Estatuto, por ter cometido um dos crimes que a comunidade internacional dos Estados considera afetar todo o seu conjunto. Ou seja, proibições de jus cogens. Esta é a razão de ser da jurisdição universal do Tribunal.

\footnotetext{
${ }^{81}$ Ibid. p. 948.

${ }^{82}$ Ibid. p. 949.
} 
O Estatuto do TPI (ou o Estatuto de Roma), é ainda formado por um total de 128 artigos e marcado pelo princípio da complementariedade. Isto é, a competência primária para processar e julgar os indivíduos acusados de cometer os crimes que afetam a sociedade internacional como um todo, ainda é dos Estados. Apenas quando estes se mostrem incapazes ou não revelem a necessária vontade para punir seus nacionais é que o Tribunal deverá atuar, tendo em vista a gravidade de tais delitos.

Os crimes referidos no preâmbulo do Estatuto são imprescritíveis e como já anteriormente mencionado podem ser subdivididos em: genocídio, crimes contra a humanidade, crimes de agressão e crimes de guerra. $\mathrm{O}$ Tribunal poderá exercer os seus poderes e funções no território de qualquer Estado-parte e, por acordo especial, no território de qualquer outro Estado. ${ }^{83}$ Daí reside a diferença entre fazer ou não parte dos Estados signatários do Estatuto: para os que não fazem, a intervenção necessita de um acordo especial.

A competência temporal relativa aos Estados-membros, se dá, pois, após sua instituição, ou seja, apenas com relação aos crimes cometidos após $1^{\circ}$ de julho de 2002. Caso um Estado se torne parte do Estatuto depois da entrada em vigor, o Tribunal somente poderá exercer sua competência para o processo e julgamento dos crimes cometidos depois da entrada em vigor do Estatuto nesse Estado - caso contrário, necessitaria do acordo especial de que trata o artigo 4.2.

Qualquer Estado parte, bem como o Conselho de Segurança das Nações Unidas, poderá denunciar ao Procurador uma situação em que haja indícios de ter ocorrido a prática de um ou vários crimes da competência do Tribunal, e solicitar a ele que a investigue. ${ }^{84} \mathrm{O}$ Procurador poderá ainda, por sua própria

\footnotetext{
${ }^{83}$ Estatuto de Roma do Tribunal Penal Internacional, artigo $4^{\circ}$, incisos $1^{\circ}$ e $2^{\circ}$. Disponível em: http://www.planalto.gov.br/ccivil_03/decreto/2002/D4388.htm. Acesso em: 27 jun. 2014.

${ }^{84}$ Estatuto de Roma do Tribunal Penal Internacional, artigos 13 e 14. Disponível em: http://www.planalto.gov.br/ccivil_03/decreto/2002/D4388.htm. Acesso em: 31 ago. 2014.
} 
iniciativa, abrir um inquérito com base em informações sobre a prática desses mesmos crimes. ${ }^{85}$ Caso o Procurador conclua que existe fundamento suficiente para abrir um inquérito, apresentará um pedido de autorização ao Juízo de Instrução, o qual irá dar a palavra final se o caso cabe na jurisdição do Tribunal. $^{86}$

O Tribunal, diferente da Corte Interamericana de Direitos Humanos, fora inicialmente composto por 18 juízes, número que pode ser aumentado por proposta de sua Presidência, que deverá fundamentar por quê considera necessária tal providência. Os juízes serão eleitos dentre pessoas de elevada idoneidade moral, imparcialidade e integridade, que reúnam os requisitos para o exercício das mais altas funções judiciais no seus respectivos países. ${ }^{87}$

O Estatuto veda expressamente a possibilidade de sua ratificação ou adesão com reservas, nos termos de seu artigo 120. Isto evita os eventuais conflitos de interpretação existentes sobre quais reservas são e quais não são admitidas pelo Direito Internacional, retirando dos países qualquer possibilidade de escusa para o cumprimento de suas obrigações.

Por fim, quanto à definição da competência material do TPI (o mais importante para o estudo em análise), a primeira delas, como já assinalado, é o crime de genocídio. Para os efeitos do Tribunal, entende-se por genocídio

qualquer um dos atos que a seguir se enumeram, praticado com intenção de destruir, no todo ou em parte, um grupo nacional, étnico, racial ou religioso, enquanto tal: a) homicídio de membros do grupo; b) ofensas graves à integridade física ou mental de membros do grupo; c) sujeição intencional do grupo a condições de vida com vista a provocar a sua destruição física, total ou parcial; d) imposição de medidas destinadas a impedir nascimentos no seio do grupo; e) transferência, à força, de crianças do grupo para outro grupo. ${ }^{88}$

\footnotetext{
85 Estatuto de Roma do Tribunal Penal Internacional, artigo 15.1. Disponível em: http://www.planalto.gov.br/ccivil_03/decreto/2002/D4388.htm. Acesso em: 31 ago. 2014.

86 Estatuto de Roma do Tribunal Penal Internacional, artigo 15.4. Disponível em: http://www.planalto.gov.br/ccivil_03/decreto/2002/D4388.htm. Acesso em: 31 ago. 2014.

${ }^{87}$ Em 2003, a juíza brasileira Sylvia Steiner foi indicada pelo governo brasileiro a uma das vagas do Tribunal e foi eleita em primeiro escrutínio pela Assembleia Geral dos Estados Partes, na sede da ONU, para um mandato de nove anos, que terminou em 2009.

88 Estatuto de Roma do Tribunal Penal Internacional, artigo $6^{\circ}$. Disponível em: http://www.planalto.gov.br/ccivil_03/decreto/2002/D4388.htm. Acesso em: 29 jun. 2014.
} 
Note-se que a elementar do tipo "genocídio" é a intenção do agente de destruir no todo ou em parte determinado grupo. ${ }^{89}$ Trata-se, mais uma vez, de positivar o que na comunidade internacional já era norma costumeira desde o período pós-guerra e que já houvera sido consolidada também na Corte Internacional de Justiça, na Opinião Consultiva emitida em 28 de maio de 1951, sobre as "Reservas à Convenção para a Prevenção e a Repressão do Crime de Genocídio”, em que tal ilícito fora tratado como crime do Direito Internacional. ${ }^{90}$

A outra competência, que trata dos crimes contra a humanidade, já é objeto de mais discussão sobre sua aplicação no âmbito do Tribunal, pois, usualmente, conota qualquer atrocidade ou violação de direitos humanos perpetrados em um contexto de ataque sistemático, para cuja punição é possível aplicar-se o princípio da jurisdição universal. Para afastar um pouco esta discussão é que tal termo não pode ser estudado sem a lembrança histórica e técnica que lhe deu origem: intimamente ligado ao massacre provocado pelos turcos contra os armênios, durante a Primeira Guerra Mundial, tendo sido esta ocorrência qualificada pela Declaração do Império Otomano como um crime da Turquia contra a humanidade. ${ }^{91}$

\footnotetext{
${ }^{89}$ Por exemplo, um simples homicídio, perpetrado com a intenção de "destruir no todo ou em parte" requerido pelo art. $6^{\circ}$ do Estatuto de Roma ou pelo art. $2^{\circ}$ da Convenção para a Prevenção e Repressão do Genocídio, é suficiente por esse simples ato para ser chamado de genocídio. Porém, ao matar aproximadamente dois milhões de cambojanos não se trata de genocídio porque tais homicídios não foram realizados por uma etnia, grupo religioso ou grupo nacional contra algum outro, mas sim, pelos mesmos nacionais, mesmo grupo religioso e mesmo grupo étnico contra seus próprios membros e por razões políticas. Uma vez que grupos políticos e sociais foram excluídos dos grupos protegidos pela Convenção do Genocídio, um assassinato em massa não é considerado genocídio, a não ser que possa ser concretamente provado que há uma diversidade entre o grupo perpetrador e o grupo vítima. Em suma, isto implica dizer que dependendo do caso, matar uma única pessoa pode ser genocídio e matar 2 milhões, não necessariamente sempre o é. Entretanto, tais assassinatos massivos podem ser incluídos no rol de outros crimes previstos pelo Estatuto - e, portanto, terem proteção da jurisdição do TPI como os crimes contra a humanidade e crimes de guerra.

${ }^{90}$ JARDIM, Tarciso Dal Maso. O Tribunal Penal Internacional e sua importância para os direitos humanos. In: O que é o Tribunal Penal Internacional. Brasília: Câmara dos Deputados/Coordenação de Publicações, 2000 (Série ação parlamentar, n. 110).

${ }^{91}$ MELLO, Celso D. de Albuquerque. Curso de direito internacional público. 14 ed. v. 2. Rio de Janeiro: Ed. Renovar. 2002. p. 935.
} 
Para o Estatuto de Roma, então, crime contra a humanidade é qualquer dos atos elencados a seguir, desde que tenham sido cometidos em um quadro de ataque generalizado ou sistemático, contra qualquer população civil, tais como:

a) homicídio; b) extermínio; c) escravidão; d) deportação ou transferência forçada de uma população; e) prisão ou outra forma de privação da liberdade física grave, em violação das normas fundamentais de direito internacional; f) tortura; g) agressão sexual, escravatura sexual, prostituição forçada, gravidez forçada, esterilização forçada ou qualquer outra forma de violência no campo sexual de gravidade comparável; h) perseguição de um grupo ou coletividade que possa ser identificado, por motivos políticos, raciais, nacionais, étnicos, culturais, religiosos ou de gênero, tal como definido no parágrafo $3^{\circ}$, ou em função de outros critérios universalmente reconhecidos como inaceitáveis no direito internacional, relacionados com qualquer ato referido neste parágrafo ou com qualquer crime da competência do Tribunal; i) desaparecimento forçado de pessoas; j) crime de apartheid; k) outros atos desumanos de caráter semelhante, que causem intencionalmente grande sofrimento, ou afetem gravemente a integridade física ou a saúde física ou mental. ${ }^{92}$

Os crimes contra a humanidade se distinguem do genocídio no tocante à intenção. O elemento intencional, no sentido de querer destruir determinado grupo nacional, étnico, racial ou religioso, não existe nos crimes contra a humanidade. ${ }^{93}$

A definição dos crimes de agressão está contida no art. $8^{\circ}$ do Acordo dos Estados-Parte de 2010, realizado em Kampala, Uganda, e assinado em 11 de junho de 2010, criado com o fito de emenda ao Estatuto. Isso porque, somente nesta data é que se teria finalmente chegado a um consenso sobre o que seria crime de agressão. Ficou ali estabelecido que uma pessoa comete crime de agressão quando, estando em condições de controlar ou dirigir efetivamente a ação política ou militar de um Estado, planeja, prepara, inicia ou realiza um ato de agressão que, por suas características, gravidade e escala constitua uma violação manifesta à Carta das Nações Unidas. ${ }^{94}$

92 Estatuto de Roma do Tribunal Penal Internacional, artigo $7^{\circ}$. Disponível em: http://www.planalto.gov.br/ccivil_03/decreto/2002/D4388.htm. Acesso em: 29 jun. 2014

${ }_{93}^{93}$ MELLO, Celso D. de Albuquerque. Op. cit., p. 934.

${ }^{94}$ MAZZUOLI, Valerio de Oliveira. Op. cit., p. 961. 
E o caso dos crimes de guerra ou dos crimes contra as leis e costumes aplicáveis em conflitos armados, são fruto de uma longa evolução do direito internacional humanitário, desde a Primeira Guerra Mundial, tendo sido impulsionado pelo Comitê Internacional da Cruz Vermelha e estão disciplinados no artigo $8^{\circ}$, inciso 2 do Estatuto de Roma.

Um destes crimes, que será objeto do julgamento do TPI a seguir analisado, é o crime de recrutamento ou alistamento de menores de 15 anos nas forças armadas nacionais ou a utilização destes para participar ativamente em hostilidades. ${ }^{95}$ Como parte majoritária da doutrina vai no sentido de que os crimes previstos no Estatuto de Roma, fazem parte do conteúdo material de jus cogens, ${ }^{96}$ o crime de recrutamento de menores também está incluído no rol e, por isso mesmo, fora objeto de escolha do presente trabalho, em demonstração que não só crimes contra a humanidade são considerados proibições de normas imperativas.

Por ser de domínio de jus cogens, estes crimes geram uma obrigação erga omnes por parte dos indivíduos de não cometê-los e por parte dos Estados de puni-los. ${ }^{97}$ Tal posição tem embasamento em: (1) pronunciamentos internacionais, ou o que pode ser chamado de opinio juris, refletindo o reconhecimento de que tais crimes são considerados parte das leis gerais costumeiras do Direito Internacional; (2) a linguagem utilizada em preâmbulos ou em outras provisões de tratados aplicáveis a estes crimes, que indicam que os mesmos possuem a mais elevada importância no Direito Internacional; (3) o grande número de Estados que têm ratificado tratados relativos a estes crimes; e (4) as investigações e os processos internacionais ad hoc aos perpetradores

95 Estatuto de Roma do Tribunal Penal Internacional, artigo 8.2.e.vii. Disponível em: http://www.planalto.gov.br/ccivil_03/decreto/2002/D4388.htm. Acesso em: 31 ago. 2014.

${ }^{96}$ Esta também foi a posição do Tribunal Internacional da antiga Iugoslávia em 1993 e do Tribunal Internacional de Ruanda ao considerar genocídio, crimes contra a humanidade e crimes de guerra como sendo jus cogens. (BASSIOUNI, M. Cherif. International Criminal Law Conventions and their penal provisions. Netherlands: Martinus Nijhoff. 1997).

${ }_{97}$ ZENOVIC, Predrag. Human rights enforcement via peremptory norms - a challenge to state sovereignt. RGSL Research Papers n. 6. Riga, 2012. p. 26-27. 
de tais delitos ${ }^{98}$ - como os crimes de guerra e contra a humanidade processados pelos Tribunais Internacionais para a antiga Iugoslávia, Ruanda e Serra Leoa.

Nas palavras de Cherif Bassiouni, ex-presidente da Comissão de peritos instituída pelo Conselho de Segurança da ONU para investigar as violações de direitos humanos na antiga Iugoslávia:

As discussed below, certain crimes affect the interests of the world community as a whole because they threaten the peace and security of humankind and because they shock the conscience of humanity. If both elements are presente in a given crime, it can be concluded that it is part of ius cogens. The argument is less compelling, though still strong enough, if only one of these two elements is present. ${ }^{99}$

Quanto à responsabilidade penal trazida pelo TPI, vale mais uma vez ressaltar que ele repete a conquista trazida pelo Tribunal de Nuremberg em 1946: a irrelevância da qualidade de oficial para ser julgado internacionalmente por determinados crimes consagrados pelo Direito Internacional. Em outras palavras, a qualidade de oficial, de Chefe de Estado ou de Governo, de membro do Parlamento ou de qualquer outra função pública, jamais poderá eximir uma pessoa de responsabilidade criminal nos termos do Estatuto de Roma. Nas palavras de Antônio Paulo Cachapuz de Medeiros:

Crimes contra o direito internacional são cometidos por indivíduos (...), e por vezes os preceitos de direito internacional fazem-se efetivos apenas com a condenação dos indivíduos que cometeram esses crimes. ${ }^{100}$

A Justiça Penal Internacional, enfim consolidada por um tribunal de jurisdição universal, nasceu então, desde o primeiro momento com o objetivo de punir e prevenir os piores e mais cruéis crimes violadores dos direitos humanos. Estes crimes trazem consigo o dever do Estado de processar ou extraditar, da não aplicabilidade de qualquer imunidade ao agente perpetrador

\footnotetext{
${ }^{98}$ BASSIOUNI, M. Cherif. International crimes: jus cogens and obligation erga omnes. In: Law and contemporary problems. Vol. 59. No. 4. 1996. p. 68.

${ }^{99}$ Ibid. p. 69.

${ }^{100}$ MEDEIROS, Antônio Paulo Cachapuz de. O Tribunal Penal Internacional e a Constituição Brasileira. In O Que é Tribunal Penal Internacional. Brasília: Centro de Documentação e Informação, 2000. p. 71.
} 
do delito, bem como a incompatibilidade de defesas como "obediência a ordens superiores” ou "estado de emergência”. Estão subjugados pela jurisdição universal independentemente de onde foram cometidos ou por quem o foram (incluindo os próprios agentes de Estado), e em qualquer contexto que tenham ocorrido (em tempos de guerra ou paz).

A respeito, para ilustrar a posição do Tribunal Penal Internacional na condenação do seu primeiro caso julgado, é que a seguir será analisado o caso “The Prosecutor v. Thomas Lubanga Dyilo”, o qual, como já mencionado, versa sobre um dos crimes de guerra previstos pelo Estatuto de Roma e, por isso mesmo, é considerado como um crime de maior gravidade, que constitui uma ameaça à paz, à segurança e ao bem-estar da humanidade. ${ }^{101} \mathrm{Em}$ outras palavras, que afeta a comunidade internacional em seu conjunto. E se uma norma imperativa internacional é aquela aceita e reconhecida pela comunidade dos Estados como um todo, os crimes que a afetam em seu conjunto, não poderiam deixar de ser por esta mesma norma, combatidos. Por isto é que as proibições de cometê-los são domínio do jus cogens.

\subsection{O caso "The Prosecutor v. Thomas Lubanga Dyilo"}

República Democrática do Congo, setembro de 2002. Tomas Lubanga Dyilo é acusado de ser responsável por recrutar e alistar crianças menores de 15 anos para a Força Patriótica para a Libertação do Congo (FLPC), braço armado do movimento rebelde União de Patriotas Congoleses (UPC), e usá-las para participar ativamente das hostilidades em Ituri, região da República Democrática do Congo, até agosto de 2003. ${ }^{102}$

Com o mandado de prisão expedido pelo TPI em maio de 2005, 7 anos depois, em 10 de julho de 2012, seu julgamento fora a primeira vez na história

\footnotetext{
101 Preâmbulo do Estatuto de Roma do Tribunal Penal Internacional. Disponível em: http://www.planalto.gov.br/ccivil_03/decreto/2002/D4388.htm. Acesso em: 3 set. 2014.

102 TRIBUNAL PENAL INTERNACIONAL. Prosecutor v. Thomas Luganba Dyilo. Caso $\mathrm{n}^{0}$ ICC01/04-01/06. 10 de julho de 2012. p. 4.
} 
que o TPI julgara violações de direitos humanos. No caso específico de recrutamento de crianças, o outro único julgamento de tribunais em comparáveis posições fora o do Tribunal Penal Internacional Especial para Serra Leoa, o qual teve sete condenados em quatro casos por usar crianças menores de 15 anos como soldados. Nas palavras da câmara de julgamento do TPI, no caso de Serra Leoa

The Trial Chamber in the RUF case, when addressing the issue of gravity, determined that the offences it was considering relating to the use of child soldiers were committed on a large scale and with a significant degree of brutality It was established that many children had been abducted from their families and they were subjected to cruel and harsh military training. Those who were unable to withstand the training regime were often summarily shot and killed. Children as young as 10 were armed and used to ambush others, as well as acting as bodyguards for the commanders. The Chamber found that "very young children were used to engage in the perpetration of gruesome crimes directed against innocent civilians", including amputating the limbs of civilians and beheading corpses. Many children were shot and killed in training and combat. The Chamber found that RUF fighters regularly drugged children, and it concluded that the inherent gravity of the criminal acts in question was "exceptionally high". ${ }^{103}$

Ademais, em consideração ao preâmbulo do Estatuto de Roma, os mais sérios crimes de interesse da comunidade internacional como um todo, não poderiam ficar impunes, justamente por fazerem parte do âmbito material das proibições de jus cogens.

O preâmbulo prevê que os Estados-partes estão determinados a por um fim à impunidade destes crimes e contribuir para a prevenção dos mesmos, em consideração às gerações presentes e futuras. Recrutar e alistar crianças para participarem das hostilidades de uma guerra armada é, sem dúvida, um destes crimes. Além disso, o crime de recrutamento é ainda mais grave no presente caso por adicionar o elemento de compulsão e, mesmo nos casos de consentimento da criança, tal defesa não poderia ser arguida para nenhum dos crimes dos quais Lubanga era réu.

\footnotetext{
${ }^{103}$ Ibid. p. 8.
} 
Porquanto, o crime de utilização de crianças para participar ativamente em hostilidades armadas envolve a exposição das mesmas a um perigo real como alvos potenciais. Como reconhecido em inúmeros tratados internacionais, a vulnerabilidade das crianças significa que elas precisam ser proporcionadas a particular proteção, diferente do resto da população em geral. Nas palavras do Tribunal,

The principal historical objective underlying the prohibition against the use of child soldiers is to protect children under the age of 15 from the risks that are associated with armed conflict, and particularly they are directed at securing their physical and psychological well-being. This includes not only protection from violence and fatal or non-fatal injuries during fighting, but also the potentially serious trauma that can accompany recruitment, including separating children from their families, interrupting or disrupting their schooling and exposing them to an environment of violence and fear. ${ }^{104}$

A Câmara de julgamento, contudo, não concluíra que Lubanga tivesse pessoalmente recrutado e alistado meninas e meninos menores de 15 anos dentro do movimento da UCP, mas sim, que como líder e coordenador do movimento, estava consciente do que estava ocorrendo, encorajava e aquiescia com isso. Pela sua anuência é que Lubanga estava sendo julgado como coperpetrador, o qual tivera uma essencial contribuição para que o plano fosse executado. Segundo a Câmara:

Thomas Lubanga was the President of the UPC/FPLC, and the evidence demonstrates that he was simultaneously the Commander-in-Chief of the army and its political leader. He exercised an overall coordinating role over the activities of the UPC/FPLC. He was informed, on a substantive and continuous basis, of the operations of the FPLC. He was involved in plarming military operations, and he played a critical role in providing logistical support, including as regards weapons, ammunition, food, imiforms, military rations and other general supplies for the FPLC troops. He was closelyinvolved in making decisions on recruitment policy and he actively supported recruitment initiatives, for instance by giving speeches to the local population and the recruits. In his speech at the Rwampara camp, he encouraged children, including those under the age of 15 years, to join the army and to provide security for the populace once deployed in the field following their military training. Furthermore, he personally used children below the age of 15 amongst his bodyguards and he regularly saw guards of

\footnotetext{
${ }^{104}$ Ibid. p. 15.
} 
other UPC/FPLC members of staff who were below the age of 15 . The Chamber has concluded that these contributions by Thomas Lubanga, taken together, were essential to a common plan that resulted in the conscription and enlistment of girls and boys below the age of 15 into the UPC/FPLC and their use to actively partidpate in hostilities. ${ }^{105}$

A Câmara não considerou, no entanto, - em uma aplicação do princípio in dubio pro reo -, que havia evidências suficientes para concluir que a violência sexual impetrada contra as crianças recrutadas era suficientemente difundida de forma a poder ser caracterizada como ocorrida no curso ordinário da implementação do plano comum, do qual Lubanga era responsável. Da mesma maneira, para a Câmara, nada sugeriu que Lubanga tivesse ordenado ou encorajado violência sexual, ou ao menos que ele estaria ciente da sua ocorrência de alguma forma que pudesse ser atribuído a ele culpa. ${ }^{106}$

Neste ponto, vale uma observação: ao passo que a Corte Interamericana de Direitos Humanos julga Estados, aplica o princípio in dubio pro homini, em uma tentativa de maior proteção às vítimas de graves violações. Por sua vez, ao julgar seres humanos, o Tribunal Penal Internacional aplica o princípio in dubio pro reo, em uma tentativa de prevenir injustiças a pessoas que se condenadas, ficarão anos presas - podendo, até mesmo, em casos excepcionais, serem condenadas à prisão perpétua. ${ }^{107}$

Por outro lado, como circunstância atenuante, fora alegado pela defesa que Lubanga assumira o posto da UPC visando a paz e não o poder, em um contexto de ameaça de massacre ou intervenção das Nações Unidas - e que os soldados eram treinados visando esse objetivo. Ainda que a Câmara tenha aceitado que a paz poderia voltar a reinar em Ituri, uma vez que Lubanga conseguisse seus objetivos, isto não obscurece o fato de que para atingi-los, ele efetivamente usou crianças como parte do exercito sob seu controle e "whether

\footnotetext{
105 Ibid. p. 21.

106 Ibid. p. 28.

107 Estatuto de Roma do Tribunal Penal Internacional, artigo 77.1.b. Disponível em: http://www.planalto.gov.br/ccivil_03/decreto/2002/D4388.htm. Acesso em: 31 ago. 2014.
} 
or not Mr Lubanga genuinely feared attacks by others, his response should not have included using children as part of the armed wing of the UPC.”108

No momento de aferição da pena, em primeiro lugar, a Câmara considerou que prisão perpétua não seria proporcional no presente caso, haja vista que o regimento da Regra 145(3) sobre as aplicações das disposições do Estatuto de Roma, prevê que uma sentença de tal porte só é "justified by the extreme gravity of the crime and the individual circumstances of the convicted person, as evidenced by the existence of one or more aggravanting circumstances." 109 Como a Câmara não achou nenhuma circunstância agravante, uma pena de prisão perpétua seria, pois, inapropriada.

Deste modo, a Câmara considerou que:

Mr Lubanga has been convicted of having committed, jointly with others, the crimes of conscripting and enlisting children under the age of 15 and using them to participate actively in hostilities in the context of an internal armed conflict. The Chamber has borne in mind the widespread recruitment and the significant use of child soldiers during the timeframe of the charges; the position of authority held by Mr Lubanga within the UPC/FPLC and his essential contribution to the common plan that resulted, in the ordinary course of events, in these crimes against children; the lack of any aggravating circumstances; and the mitigation provided by his consistent cooperation with the Court during the entirety of these proceedings, in circumstances when he was put under considerable unwarranted pressure by the conduct of the prosecution during the trial, as set out above. ${ }^{110}$

A Câmara, então, sentenciou Lubanga a 13 anos de prisão por ter cometido, em conjunto com outras pessoas o crime de recrutamento de crianças menores de 15 anos para a UPC; a 12 anos de prisão, por ter cometido, em conjunto com outras pessoas o crime de alistamento de crianças menores de 15 anos para a UPC; e a 14 anos de prisão, por ter cometido, em conjunto com outras pessoas, o crime de usar crianças menores de 15 anos para participar ativamente das hostilidades em Ituri.

\footnotetext{
108 TRIBUNAL PENAL INTERNACIONAL. Prosecutor v. Thomas Luganba Dyilo. Caso $\mathrm{n}^{\circ}$ ICC01/04-01/06. 10 de julho de 2012. p. 33.

${ }^{109}$ Ibid. p. 35.

${ }^{110}$ Ibid. p. 36
} 
Isto tudo, em violação ao artigo 8.2.e.vii do Estatuto de Roma, bem como, de acordo com o artigo 25.3.a do mesmo Estatuto, que trata da responsabilidade criminal do indivíduo, in verbis:

Nos termos do presente Estatuto, será considerado criminalmente responsável e poderá ser punido pela prática de um crime da competência do Tribunal quem: cometer esse crime individualmente ou em conjunto ou por intermédio de outrem, quer essa pessoa seja, ou não, criminalmente responsável(...). ${ }^{111}$

A pena única total de Thomas Lubanga fora, então, fixada em 14 anos, em consonância com o artigo 78.1, o qual prevê que:

Se uma pessoa for condenada pela prática de vários crimes, o Tribunal aplicará penas de prisão parcelares relativamente a cada um dos crimes e uma pena única, na qual será especificada a duração total da pena de prisão. Esta duração não poderá ser inferior à da pena parcelar mais elevada e não poderá ser superior a 30 anos de prisão ou ir além da pena de prisão perpétua prevista no artigo 77 , parágrafo $1_{-}^{\circ}$, alínea $b$ ). ${ }^{112}$

Não obstante, será descontado ainda o tempo em que ficara preso a mando do Tribunal, a saber, 6 anos, tendo em vista que fora detido em 16 de março de 2006. Ademais, vale consignar que nenhuma outra reparação fora determinada e que a decisão não fora unânime.

A opinião dissidente do juiz Odio Benito fora no sentido contrário à maioria quando esta não levou em conta a ampla evidência das péssimas condições em que garotos e garotas eram recrutado(a)s e todos os danos sofridos como resultado de seus envolvimentos com a UPC.

Em sua opinião, as evidencias de punições e terríveis condições de vida, assim como a gravidade dos danos causados, como discriminação de gênero, violência sexual de garotas e garotos menores de 15 anos e consequentes gravidezes, abortos, HIV e outras doenças sexualmente transmissíveis - tudo isso resultado do recrutamento - levariam a uma outra resposta penal. Para o juiz, tais fatores deveriam ter sido levados em consideração como

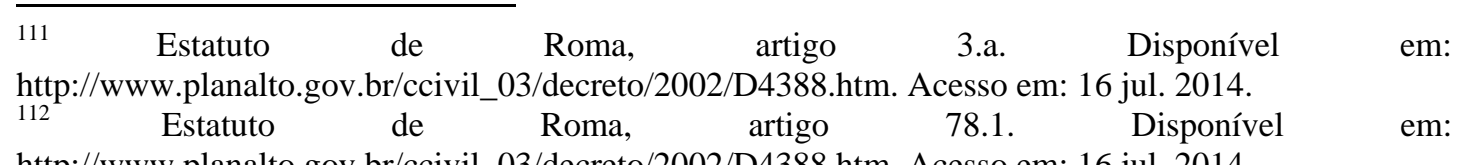
http://www.planalto.gov.br/ccivil_03/decreto/2002/D4388.htm. Acesso em: 16 jul. 2014. 
circunstâncias agravantes na sentença ao se decidir sobre a gravidade do crime perpetrado, e em especial ao dano causado às crianças e as suas famílias em resultado deste crime.

Nas palavras de Odio Benito,

Their childhood was deeply affected by these crimes that have scarred their lives and those of their families forever. Consequently, I deem that these are exacerbating factors pursuant to Rule 145(l)(c) of the Rules, all of which may be attributed to Mr Lubanga since he was found guilty beyond reasonable doubt of the crimes that caused such harms to the child victims and their families. ${ }^{113}$

Porém, importante mesmo para o tema aqui debatido é consignar que em seu "leading-case", a Corte Penal Internacional - ou mesmo o juiz dissidente - não fundamentara sua condenação expressamente por violação à uma norma imperativa de Direito Internacional, mas somente pela violação ao Estatuto de Roma - o que, como já visto, dá no mesmo. O Tribunal Penal Internacional nem precisa se utilizar do termo para consignar que está julgando uma violação de norma imperativa, tendo em vista que os crimes de sua competência previstos no Estatuto de Roma já o são por essência: afetam a consciência da comunidade internacional como um todo.

No entanto, diferente da Corte Interamericana de Direitos Humanos, por considerar que sua competência temporal é tão somente dos crimes cometidos após a entrada em vigor do Estatuto, o TPI não chega a analisar casos que ficariam fora de sua abrangência, ainda que abrangidos pelo poder do jus cogens, como o fez a Corte Interamericana no caso de Almonacid Arellano.

É notório, portanto, a discrepância entre as duas Cortes: levando em consideração que uma condena Estados, e geralmente sobre violações que ocorreram em um passado já relativamente distante (lapso temporal não existente no TPI), se utiliza de todas as fontes que o Direito Internacional têm para oferecer. Por outro lado, o TPI, com um poder persecutório para julgar

\footnotetext{
113 Dissenting Opinion of judge Odio Benito. In: TRIBUNAL PENAL INTERNACIONAL. Prosecutor v. Thomas Luganba Dyilo. Caso n ${ }^{\circ}$ ICC-01/04-01/06. 10 de julho de 2012. p. 50.
} 
indivíduos, apresenta uma atividade mais restrita, a qual se atrela ao Estatuto, mas que nem por isso, deixa de tratar de norma imperativa - muito pelo contrário, aplicar o Estatuto é a prova máxima de estar-se falando de crimes que ultrajam a consciência da humanidade e que, por isso mesmo, como já supracitado, geram obrigações erga omnes dos indivíduos de não cometê-los e dos Estados de puni-los.

Em ambos os casos, entretanto, podemos ver a proteção do indivíduo: de um lado, a Corte Interamericana se utiliza de todo um arcabouço jurídico e doutrinário para condenar o Estado e proteger a pessoa humana que tivera seu direito violado. De outro, o TPI dá garantias mínimas ao indivíduo que está sendo julgado (como não julgar fatos que ocorreram antes da entrada em vigor do Estatuto de Roma, aplicar o princípio in dubio pro reo, dentre outros), em uma tentativa de não abrir precedentes para violações futuras. 


\section{CONSIDERAÇÕES FINAIS}

As normas cogentes internacionais surgiram como expressão máxima dos princípios que nortearam a criação dos direitos humanos. Para impedir que atrocidades como as do início do século XX voltassem a ocorrer, as normas imperativas limitaram a soberania dos Estados de uma forma nunca antes vista: trouxeram nulidade a qualquer tratado que as derrogassem. São normas aceitas e reconhecidas pela comunidade dos Estados como a expressão máxima do principio da dignidade da pessoa humana, que acordo multilateral nenhum pode infirmar, sob pena de se estar negando a própria dignidade.

Em uma interpretação mais ampla, derivada da obrigação erga omnes de respeitá-las, há no plano internacional, a nulidade dos atos jurídicos nacionais incompatíveis com estas normas, bem como a necessidade de punição dos indivíduos tipificados nas suas proibições. É este o caso dos crimes contra a humanidade. Em uma verdadeira aula de direitos humanos, no caso "Almonacid Arellano y otros vs. Chile”, a Corte Interamericana veio explicar com maestria o motivo da impossibilidade destes crimes em leis de anistia: violar norma imperativa internacional. Ademais, deixou consignado que além destas normas não serem passíveis de anistia, são também imprescritíveis e a obrigação de serem respeitadas não sucumbe sob os argumentos de irretroatividade da lei penal, bis in idem ou reserva legal.

O rol das proibições de jus cogens não se limitou, contudo, aos crimes de lesa humanidade. Entrou em vigor em 1 de julho de 2002, o Estatuto de Roma, o qual positivou o entendimento já sedimentado há muito na comunidade internacional de que o crime de genocídio, os crimes de guerra e os crimes de agressão também ofenderiam a consciência da humanidade. Por isso mesmo é que deveriam ser tratados de forma diferente: sob a égide do princípio da jurisdição universal e da responsabilidade criminal do indivíduo, a criação do Tribunal Penal Internacional foi outro grande passo para uma 
identificação mais sólida das ditas normas imperativas, haja vista que todos os crimes por ele julgados o são, como fora o caso do julgamento dos crimes praticados por Thomas Lubanga Dyilo, da República Democrática do Congo, primeiro julgamento do TPI.

Tal julgamento teve fundamental importância para mostrar que não só tribunais de exceção são capazes de julgar crimes de guerra. E julgou com destreza, levando em consideração que recrutar e alistar crianças (ou como chefe do partido, estar consciente do recrutamento e alistamento) requer uma resposta penal baseada na responsabilidade internacional, por tudo o que significa e acarreta na vida dessas crianças - mas sem deixar de respeitar determinadas garantias mínimas.

Ainda que longe do ideal, os importantes passos na construção de direitos humanos cada vez mais efetivos e inclusivos não podem deixar de serem reconhecidos. Foi isto que o presente estudo tentou elucidar. A busca pela proteção internacional do indivíduo é um fenômeno relativamente recente na história, mas conquistas como limitação da soberania, responsabilidade internacional do Estado independentemente de tratado, nulidade de disposições internas incompatíveis com os princípios do Direito Internacional geral, responsabilidade criminal do indivíduo, jurisdição universal, dentre outras, são conquistas poderosas. Trazidas pelas normas imperativas em um contributo para um mundo mais próximo do que deveria ser. E será. 


\section{REFERÊNCIAS BIBLIOGRÁFICAS}

ABELLO-GALVIS, Ricardo. Introducción al estúdio de las normas de ius cogens en el seno de la Comisión de Derecho Internacional, CDI. Colombia: Ed. Facultad de Jurisprudencia de La Universidad Del Rosario Centro Editorial Rosarista, 2003.

ALMEIDA, João Marques de. A Paz de Westfália - A História do Sistema de Estados Modernos e a Teoria das Relações Internacionais. In: Política Internacional. V. 2. No 18. Outono-Inverno. Lisboa, 1998.

BASSIOUNI, M. Cherif. International crimes: jus cogens and obligation erga omnes. In: Law and contemporary problems. Vol. 59. No. 4. 1996.

BASSIOUNI, M. Cherif. International Criminal Law Conventions and their penal provisions. Netherlands: Martinus Nijhoff. 1997.

BERNARDES, Marcia Nina. Sistema Interamericano de Direitos Humanos como Esfera Pública Transnacional: aspectos jurídicos e políticos da implementação de Decisões Internacionais. In: SUR. Revista Internacional de Direitos Humanos. v. 1, n. 1, jan 2004. São Paulo. 2004.

CHILE. Decreto-lei $\mathrm{n}^{0} 2.191$ de 18 de abril de 1978. Disponível em : http://www.archivochile.com/Poder_Dominante/pod_publi_parl/PDparlamento 0005.pdf. Acesso em 21 ago 2014.

COMPARATO, Fábio Konder. A afirmação histórica dos direitos humanos. 3 ed. São Paulo: Saraiva, 2003.

CONVENÇÃO AMERICANA DE DIREITOS HUMANOS. In: Wikipédia: a enciclopédia

livre.

Disponível

em: 
http://pt.wikipedia.org/w/index.php?title=Conteúdo_aberto\&oldid=15696001. Acesso em: 6 jul. 2014.

CONVENÇÃO DE VIENA SOBRE DIREITO DOS TRATADOS. Disponível em: http://www.planalto.gov.br/ccivil_03/_Ato20072010/2009/Decreto/D7030.htm. Acesso em: 31 ago. 2014.

CORTE INTERAMERICANA DE DIREITOS HUMANOS. Caso Almonacid Arellano y otros vs. Chile. 2006.

CORTE INTERAMERICANA DE DIREITOS HUMANOS. Caso Barrios Altos vs. Peru. 2001.

CORTE INTERAMERICANA DE DIREITOS HUMANOS. Caso Goiburú y otros vs. Paraguai. 2006.

DIXON, Martin; McCORQUODALE Robert. Cases $e$ materials on international law. 4th ed. United Kingdom: Oxford University Press, 2003.

ESTATUTO DE ROMA DO TRIBUNAL PENAL INTERNACIONAL. Disponível em: http://www.planalto.gov.br/ccivil_03/decreto/2002/D4388.htm. Acesso em: 27 jun. 2014.

GOUVEIA, Jorge Barcelar. Direito Internacional Penal - uma perspectiva dogmático-jurídica. Portugal: Livraria Almedina, 2008.

HABERMAS, Jurgen. El concepto de dignidad humana y la utopia realista de los derechos humanos. Trad. Javier Aguirre Román. Rev. Eduardo Mendieta y María Herrera. Dianóia, vol. LV, nº 64, 2010.

HILDEBRANDO, Accioly; G.E. do Nascimento e Silva; CASELLA, Paulo Borba. Manual de Direito Internacional Público. 17 ed. São Paulo: Ed. Saraiva, 2009. 
IN LARGER FREEDOM: TOWARDS DEVELOPMENT, SECURITY AND HUMAN RIGHTS FOR ALL. Report of the Secretary-General. In: United Nations. Disponível em http://www.un.org/largerfreedon/contents.htm. Acesso em: 27 jun. 2014.

JARDIM, Tarciso Dal Maso. O Tribunal Penal Internacional e sua importância para os direitos humanos. In: O que é o Tribunal Penal Internacional. Brasília: Câmara dos Deputados/Coordenação de Publicações, 2000 (Série ação parlamentar, n. 110).

JULGAMENTOS DE NUREMBERG. In: Wikipédia: a enciclopédia livre. Disponível em: http://pt.wikipedia.org/wiki/Julgamentos_de_Nuremberg. Acesso em: 19 jul. 2014.

KALECK Wolfgang; RATNER Michael; SINGELSNTEIN Tobias; WEISS Peter. International prosecution of human rights crimes. New York: Springer, 2006.

LAFER, Celso. A reconstrução dos direitos humanos: um diálogo com o pensamento de Hannah Arendt. São Paulo: Companhia das Letras, 1988.

MAZZUOLI, Valerio de Oliveira. Curso de Direito Internacional Público. 5 ed. São Paulo: Editora Revista dos Tribunais, 2011.

MEDEIROS, Antônio Paulo Cachapuz de. O Tribunal Penal Internacional e a Constituição Brasileira. In O Que é Tribunal Penal Internacional. Brasília: Centro de Documentação e Informação, 2000.

MELLO, Celso D. de Albuquerque. Curso de direito internacional público. 14 ed. v. 2. Rio de Janeiro: Ed. Renovar. 2002. 
O QUE É A CIDH. In: Organização dos Estados Americanos - democracia para a paz, segurança e desenvolvimento. Disponível em: http://www.oas.org/pt/cidh/mandato/que.asp. Acesso em: 6 jul. 2014.

PIOVESAN, Flávia. Direitos Humanos e o Direito Constitucional Internacional. 13 ed., rev. e atual. São Paulo: Ed. Saraiva, 2012.

REZEK, Francisco. Direito internacional público: curso elementar. 14 ed. São Paulo: Saraiva, 2013.

SHAW, Malcolm N. Internacitional Law. 5th ed. United Kingdom: Crambridge University Press, 2003.

TRIAL OF THE MAJOR WAR CRIMINALS BEFORE THE INTERNATIONAL MILITARY TRIBUNAL. Nuremberg, 1947. p. 218. In: Library of Congress. Disponível em: http://www.loc.gov/rr/frd/Military_Law/pdf/NT_Vol-I.pdf. Acesso em: 24 out. 2014.

TRIBUNAL PENAL INTERNACIONAL. The Prosecutor v. Thomas Luganba Dyilo. Caso no ICC-01/04-01/06. 10 de julho de 2012.

TRINDADE, Antonio Augusto Cançado. Derecho Internacional de los Derechos Humanos - Essencia y Trascendencia (Votos em la Corte Interamericana de Derechos Humanos, 1991-2006), México: Edit. Porrúa/Universidad Iberoamericana, 2007.

TRINDADE, Antonio A. Cançado. La ampliación del contenido material del ius cogens. XXXV Curso de Derecho Internacional Organizado por el Comité Jurídico Interamericano - 2008. Washington D.C.: Secretaría General de la OEA, 2009. 
TRINDADE, Antônio Augusto Cançado. O direito internacional em um mundo em transformação. Rio de Janeiro: Renovar, 2002.

TRINDADE, Antonio Augusto Cançado. Os Tribunais Internacionais Contemporâneos. Brasília: FUNAG, 2013.

TRINDADE, Antônio Augusto Cançado. Tratado Internacional dos Direitos Humanos. Vol. I. $2^{\text {a }}$ edição. Porto Alegre: Sergio Antonio Fabris Editor, 2003.

VARELLA, Marcelo Dias. Direito Internacional Público. 2 ed. São Paulo: Ed. Saraiva, 2010.

ZENOVIC, Predrag. Human rights enforcement via peremptory norms - a challenge to state sovereignt. Riga: RGSL Research Papers, 2012. 